\title{
Community, Solidarity and Multilingualism in a Transnational Social Movement
}

Community, Solidarity and Multilingualism in a Transnational Social Movement presents a critical sociolinguistic ethnography of the Emmaus movement that analyses linguistic and discursive practices in two local communities in order to provide insight into solidarity discourses and transnational communication more broadly. Integrating perspectives from a range of disciplines, the monograph seeks to understand the ways in which social movements are maintained across disparate communities grounded in shared cultural referents and communicative practices but not necessarily a shared language. The book focuses on Emmaus, the solidarity movement that emerged in post-war France which brings formerly marginalised people together with others looking for an alternative lifestyle into live-in communities dedicated to recycling work and social projects.

The book first offers a historical overview of the Emmaus movement more generally, moving into an account of its development and spread across national and linguistic borders. The volume draws on data from two Emmaus communities in Barcelona and London to analyse the everyday communicative and discursive practices that appropriate and resignify the shared transnational movement ideas in different sociopolitical, economic, historical and linguistic contexts.

Community, Solidarity and Multilingualism in a Transnational Social Movement considers the social implications of local practices on the situated (re)production and evolution of transnational social movements more generally and will be of particular interest to students and researchers in sociolinguistics, linguistic anthropology, discourse studies, cultural studies and sociology.

Maria Rosa Garrido Sardà is Lecturer in English Linguistics at the University of Lausanne (Switzerland). She holds a PhD from the Universitat Autònoma de Barcelona and has previously been a postdoctoral researcher at the Institute of Multilingualism (University of Fribourg). 


\section{Routledge Critical Studies in Multilingualism}

Edited by Marilyn Martin-Jones, MOSAIC Centre for Research on Multilingualism, University of Birmingham, UK and Joan Pujolar Cos, Universitat Oberta de Catalunya, Spain

16 Language and Culture on the Margins

Global/Local Interactions

Edited by Sjaak Kroon and Jos Swanenberg

17 Agency in Language Policy and Planning

Critical Inquiries

Edited by Jeremie Bouchard and Gregory Paul Glasgow

18 Researching Agency in Language Policy and Planning Edited by Gregory Paul Glasgow and Jeremie Bouchard

19 Critical Perspectives on Linguistic Fixity and Fluidity Languagised Lives

Edited by Jürgen Jaspers and Lian Malai Madsen

20 Bilingual Parent Participation in a Divided School Community Julia Menard-Warwick

21 The Aesthetics and Politics of Linguistic Borders Multilingualism in Northern European Literature Edited by Heidi Grönstrand, Markus Huss and Ralf Kauranen

22 New Speakers of Irish in the Global Context New Revival?

Bernadette O’Rourke and John Walsh

23 Community, Solidarity and Multilingualism in a Transnational Social Movement

A Critical Sociolinguistic Ethnography of Emmaus Maria Rosa Garrido Sardà

For more information about this series, please visit: https://www. routledge.com/Routledge-Critical-Studies-in-Multilingualism/bookseries/RCSM09 


\section{Community, Solidarity and Multilingualism in a Transnational Social Movement}

A Critical Sociolinguistic Ethnography of Emmaus

Maria Rosa Garrido Sardà 
First published 2021

by Routledge

52 Vanderbilt Avenue, New York, NY 10017

and by Routledge

2 Park Square, Milton Park, Abingdon, Oxon, OX14 4RN

Routledge is an imprint of the Taylor \& Francis Group, an informa business

(C) 2021 Taylor \& Francis

The right of Maria Rosa Garrido Sardà to be identified as author of this work has been asserted by her in accordance with sections 77 and 78 of the Copyright, Designs and Patents Act 1988.

All rights reserved. No part of this book may be reprinted or reproduced or utilised in any form or by any electronic, mechanical, or other means, now known or hereafter invented, including photocopying and recording, or in any information storage or retrieval system, without permission in writing from the publishers.

Trademark notice: Product or corporate names may be trademarks or registered trademarks, and are used only for identification and explanation without intent to infringe.

Library of Congress Cataloging-in-Publication Data

A catalog record for this title has been requested

ISBN: 978-0-367-14352-7 (hbk)

ISBN: 978-0-429-03144-1 (ebk)

Typeset in Sabon

by codeMantra 
To Rosa, José and Núria 

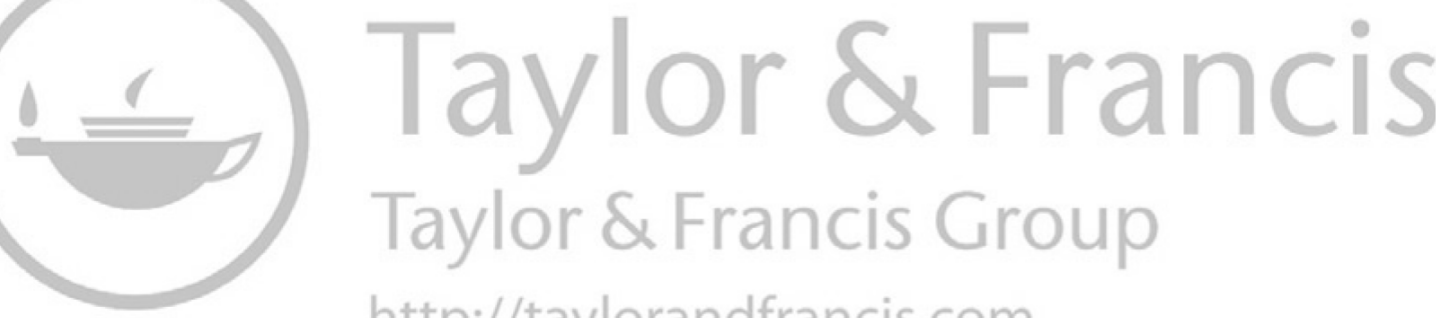
http://taylorandfrancis.com 


\section{Contents}

List of Figures $\quad$ xi

Acknowledgements xiii

1 Language, Discourse and Transnationalism in a Social Movement

1.1 Emmaus as a Holistic Social Movement 1

1.2 Investigating Sociolinguistic Articulation across Borders 6

1.3 Critical Ethnographic Sociolinguistics 9

1.4 Key concepts 13

1.4.1 Transnational Social Movements 13

1.4.2 Community 15

1.5 An Ethnographic Journey into a Transnational Field 17

1.5.1 Access, Collaboration and Positioning 19

1.5.2 An Ethnographic Toolbox 22

1.6 Structure of the Book 25

2 Historicising the Transnational Expansion of a Social Movement through Key Events and Texts

2.1 Introduction 34

2.2 Transnational and Multilingual Expansion of a French Movement 36

2.2.1 Foundation and "Catacombs" Period (1949-1954) 37

2.2.2 "Insurrection of Goodness" in France (1954) and Early Expansion (1955-1969) 40

2.2.3 From the First World Assembly (1969) to the Politicisation of the Movement (1988) 43

2.3 Historicising Religion and Politics in Two Different Emmaus Communities 48

2.3.1 Faith Traditions and Socio-Political Activism 48

2.3.2 Emmaus Barcelona: Progressive Catholicism and Post-'68 Activism 52

2.3.3 Emmaus London: Charity and Social Enterprise 57

2.4 Concluding Remarks: A Solidarity Mission Over Time 63 
viii Contents

3 Transnational Articulation and Socialisation through the Emmaus Founding Story

3.1 Introduction 67

3.2 Conceptual Framework: Collective Identity through Narrative Chronotopes 70

3.3 "A Story of Us": A Chronotopic Analysis of the Emmaus Origin Story 74

3.4 An Ethnographic Analysis of the Movement's Founding Story 77

3.4.1 "Stories of Us": Oral Storytelling and Semiotic Artefacts 78

3.4.2 "Stories of Self": Personal Narratives of Transformation 86

3.5 Concluding Remarks: Creating Sameness in the Emmaus Social Movement 93

4 Discursive Localisations of Solidarity in Two Socio-Political Contexts

4.1 Introduction 97

4.2 "Towards Other Reasons to Live": AlterGlobalisation Discourses in Emmaus Barcelona 100

4.2.1 Snapshot: "Stories of Now" in Socio-Political Activism 100

4.2.2 Zooming In: A Residential Project for Migrants 108

4.3 "Emmaus, the Homeless Charity that Works":

Discourses of Reciprocity and Skilling in the UK 114

4.3.1 Snapshot: "Stories of Now" in Homeless Activation 114

4.3.2 Zooming In: Voluntary Work Schemes for the Homeless 119

4.4 Concluding Remarks: Transnational Trends, Nation-State Regimes and Individual Trajectories 127

5 Language Ideologies for Negotiating Positioning in the Emmaus Social Movement

5.1 Introduction 133

5.2 Two Distinct Visions of Emmaus as a Movement 136

5.2.1 Emmaus as a "Multi-National of the Heart" 136

5.2.2 Emmaus as a Rhizomatic Network 142

5.3 Constructing Positioning in Emmaus through

Language Ideologies 145

5.3.1 Deproblematising Language: French and Spanish as Lingua Francas in a Catalan Community 145 
5.3.2 Problematising Language: Tensions between

English and French in a Recent English Community 150

5.4 Concluding Remarks: Ideologies of Multilingualism

and Positioning in the Movement 156

6 Linguistic Nationalism and Multilingualism

in Local Emmaus Communities

6.1 Constructing Language: Between Fixity

and Fluidity in Localities 161

6.2 Fitting into (Linguistic) Nationalism 164

6.2.1 Emmaus London: Constructing a Monolingual

Regime in an English Charity 164

6.2.2 Emmaus Barcelona: Tensions between

Monolingual and Bilingual Norms in Catalonia 172

6.3 Backgrounding Multilingualism in Everyday Practices 180

6.3.1 Emmaus London: Erasure of Multilingual

Biographies 180

6.3.2 Emmaus Barcelona: Multilingualism and New

Migrants 184

6.4 Concluding Remarks: Nationalist Ideologies in a

Transnational Social Movement 187

7 Language, Transnational Solidarity and Utopia in an Imagined Community

7.1 Emmaus as a Utopia of "Walking Words" 194

7.2 What's the (Hi)story? Key Findings about Emmaus as a Social Movement 197

7.3 Towards a Sociolinguistics of Transnationalism 200

7.4 What Now? The Story Continues 204

Appendix 1: Universal Manifesto of the Emmaus

movement (1969)

209

Appendix 2: Abbé Pierre's Radio Appeal on 1 February 1954 (Short Version)

Appendix 3: Orientations - Proposals - Questions

Adopted at the Sixth Emmaus International General

Assembly in Verona (1988)

Appendix 4: Transcription Conventions 215

Index 

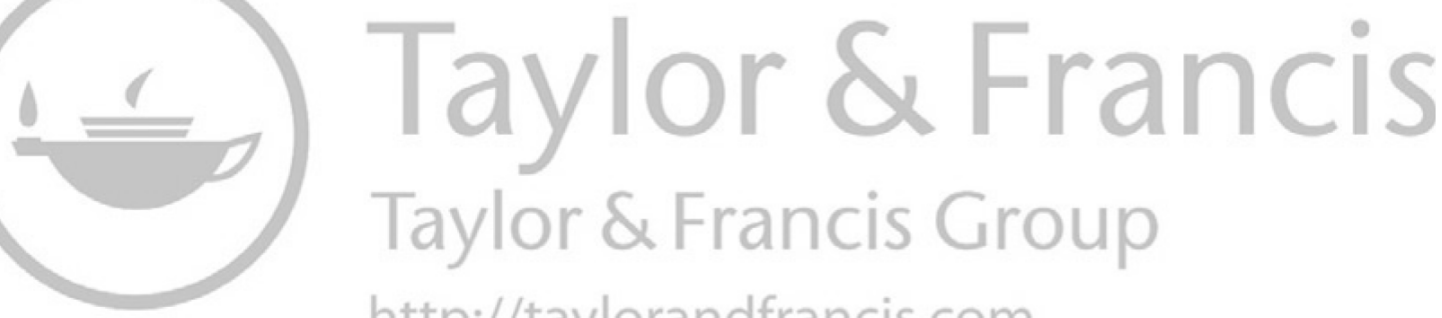
http://taylorandfrancis.com 


\section{Figures}

1.1 Dining room in Emmaus Barcelona, 2012. Pictures

taken by Maria Rosa Garrido Sardà, with permission of the community

1.2 Second-hand shop, Emmaus Barcelona. Photo by Ivan Barrios Andelo, reproduced with permission

2.1 Pictures of the three founders of the Emmaus movement on a leaflet (date unknown). OEmmaus International, Abbé Pierre's sole legatee. From left to right: Georges Legay's passport photograph (1965), ANMT 2011 39 540, Portrait of Abbé Pierre (1986), by Roger Dick, ANMT 201139385 and Lucie Coutaz in the Esteville gardens, (July 1966), by Roger Dick, ANMT 201139690

2.2 A crèche of discourses, Emmaus Barcelona, Christmas 2011. Picture taken by Maria Rosa Garrido Sardà with permission of the community

2.3 Fundraising leaflet produced for Emmaus Cambridge in 1991. Donated by the Emmaus UK Appeal Coordinator at that time. Reproduced with permission of Emmaus UK

3.1 Outside mural at Emmaüs Étagnières (Switzerland), May 2019. Painted by former companion Romano Carboni. Picture taken by Maria Rosa Garrido Sardà

4.1 Information leaflet cover, Emmaus Barcelona, collected in 2010

4.2 Information leaflet inside, Emmaus Barcelona, collected in 2010

4.3 Nines solidàries [solidarity dolls], second-hand shop, Emmaus Barcelona. February 2012. Picture taken by Maria Rosa Garrido Sardà with permission of the community

5.1 «Monsieur l'Abbé, comment va votre multinationale?" Charles de Gaulle. Centre Abbé Pierre Emmaüs Esteville, Mouvement Emmaüs exhibition, August 2015. Picture taken by Maria Rosa Garrido Sardà, reproduced with permission 
xii Figures

5.2 World map of the EI groups, December 2015.

(C) Emmaus International, Abbé Pierre's sole legatee

6.1 Picture of a decorated Emmaus London shop front, May 2012. Picture by Maria Rosa Garrido Sardà with permission of the community

7.1 "Together towards other reasons to live, EMMAUS: a flight towards utopia", artwork by Mireia Navarro in Emmaus Barcelona, March 2012. Picture by Maria Rosa Garrido Sardà with permission of the community 


\section{Acknowledgements}

"Books are the products not just of minds, but also of lives" (Calacci, 2020, p. 5)

Acknowledgements break the stereotype of the lone researcher at work and "instead expose the messy interplay of institutional support, finances, intellectual genealogies and interpersonal chaos that shape how an idea is brought into the world" in the political economy of academic life (Calacci, 2020, p. 2). Although I am the named author of this book, many different people and several institutions have made the ethnographic research behind this monograph possible. Knowledge production is never, in my opinion, an individual enterprise and I have been lucky enough to shape the ideas in this research thanks to a myriad of interactions with fellow scholars, study participants, stakeholders in different organisations, my students, as well as friends and family.

Les meves primeres paraules d'agraïment són per a totes les persones anònimes que m'han permès compartir les seves vides diàries en l'òrbita d'Emmaús i que de manera desinteressada m'han ajudat a entendre aquest moviment social des de la seva experiència personal. No tinc prou paraules d'agraïment per l'acollida amb els braços oberts, els materials que m'heu proporcionat i les converses que hem mantingut al llarg dels anys. My first expression of gratitude goes to all the anonymous people who allowed me to share their everyday lives in Emmaus and who selflessly helped me to understand this social movement from their personal experiences. I cannot thank you enough for the warm welcome and on-going conversations during and after my fieldwork in London. Je tiens aussi à remercier la communauté Emmaüs Étagnières en Suisse, spécialement Paul Dubath, pour leur aide pendant la rédaction de ce manuscrit. I am much obliged to Rosanne Palmer at Emmaus UK, as well as Emmanuelle Larcher, Brigitte Mary, Raphaëlle Monnet and Nathalie Pere-Marzano at Emmaus International for facilitating my access to documents and their reproduction permissions. I would like to especially thank Florine Catteau at the Archives Nationales $d u$ Monde $d u$ Travail in Roubaix (France) for her invaluable support in my archival research. The views expressed in this research are those of the author 


\section{xiv Acknowledgements}

and do not necessarily reflect the positioning of any Emmaus community, Emmaus Spain, Emmaus UK or Emmaus International.

I would like to thank series editors Joan Pujolar and Marilyn Martin-Jones for believing in this project and for this wonderful opportunity. I am also indebted to Elysse Preposi, Helena Parkinson and Allie Simmons at Routledge who patiently guided me through this process as a first-time author. Thanks to Hannah Davis for proofing this book, and doing such a good job, and to Mathieu Ochsenbein for his technical assistance with this manuscript.

I would like to express my deepest gratitude to Eva Codó for her unconditional support over the years. I am the researcher that I am today as a result of her careful supervision of this piece of research in addition to our countless conversations about ethnography. I would also like to thank all the members of the CIEN research team, where I grew as a researcher and where I worked as a research assistant from 2008 to 2012. I am much obliged to Melissa G. Moyer, the leader of this research team, who has believed in me since I was a third-year undergraduate in her sociolinguistics course. I would like to thank Maria Sabaté i Dalmau, Monica Heller, Alexandre Duchêne and Gabriele Budach for their comments, insights and suggestions since the early stages of my research. I am also grateful to Susan Gal and Celia Roberts for the opportunity to learn from them during my research stays at the University of Chicago (2011) and King's College London (2012) respectively. I am forever indebted to Alexandre Duchêne for all his encouragement, advice and guidance, especially since I moved to Switzerland in 2015. I would like to thank Kit Woolard for her sound advice, learning opportunities and continued interest in my work over the years.

I would like to acknowledge all the colleagues who have commented on my work about Emmaus over the years. First of all, I want to express my gratitude to my "writing buddy" Elisabeth Barakos, with whom I have had the pleasure of sharing the journey of writing our respective books and who has provided invaluable feedback on the chapters. I would also like to thank the sociolinguists at the Institute of Multilingualism (University of Fribourg) for their feedback and suggestions on Chapter 5, as well as Kori Allan, Eva Codó, Kamilla Kraft, Zorana Sokolovska and Anne-Christel Zeiter for their comments on other individual chapters. My work has also greatly benefited from the community support and discussions in the Language and Work Group. I am obliged to Miguel Pérez-Milans for the conversations that nourished my conclusions.

I have been very lucky to work with people who have encouraged me in my writing. I would like to express my sincere gratitude to the "internal workshop" participants at the University of Fribourg as well as Juliette Vuille, Anita Auer, Jennifer Thorburn, Camille Marshall, Tino Oudesluijs, Eva Suarato Adams Sabino, Marie Walz and Beatriz Duarte Wirth at the University of Lausanne. I would also like to thank 
my students at both universities, as well as the University of Strasbourg, who showed interest in my research and asked key questions about this ethnography.

Writing a book requires not only institutional and scholarly support, but also an intricate web of interpersonal relationships that is hard to do justice to here. Moltes gràcies als meus pares, la Rosa i el José, i a la meva germana Núria que m'han recolzat durant tot el llarg procés de recerca des de 2010. I want to heartily thank the person who has been by my side throughout the entire writing process, Mathieu Ochsenbein. He has been an unfailing source of enthusiasm and he has done everything possible to facilitate my task. I also want to thank my family for all the encouragement, often from a distance, especially Sandra, Mari and Mahmoud. Encara que no encara no sàpiga parlar, voldria agrair tots els somriures (virtuals) de l'Adam. No m'oblido de la Nina, que m'ha fet molta companyia mentre escrivia. Voldria agrair de tot cor la comprensió dels meus amics i de les meves amigues que m'han vist molt menys $i$ que han fet tot el posible per continuar en contacte mentre escrivia el llibre. Gràcies de tot cor per les visites, per les converses i pels ànims. My $\mathrm{PhD}$ sisters Carme Andrés and Angelica Carlet have been my rock and I can't thank them enough for all the support and advice.

The research for this book was possible thanks to the pre-doctoral research grants 2008UAB 2015 (Universitat Autònoma de Barcelona, UAB), ESTPIF 2010-23 (UAB) and 2011 BE-DGR 0039 (Agència de Gestió d'Ajuts Universitaris i de Recerca, AGAUR), and the research projects HUM 2010-26964 (Ministerio de Ciencia, Innovación y Universidades) and 2009 SGR 1340 (AGAUR) awarded to the CIEN research team at the Universitat Autònoma de Barcelona. SAUTE (Swiss Association of University Teachers of English) also provided financial support for my archival work in Roubaix (France) in 2019. I wrote this book during my four-year lectureship at the University of Lausanne that gave me the time to dedicate to this book project.

Chapter 4 (Sections 4.2.1 and 4.3.1) is derived in part from Maria Rosa Garrido, "Circulation and localization of a transnational founding story in a social movement", in Adriana Patiño-Santos \& Ana María Relaño-Pastor (Eds.), Storytelling in globalized spaces: A Linguistic ethnographic perspective. International Journal of the Sociology of Language, 250, 2018, Berlin, De Gruyter, pp. 113-135.

Chapter 6 (Section 6.2.1) is derived in part from Maria Rosa Garrido, “The homeless charity that works': A critical sociolinguistic analysis of charity discourses and English-only ideologies in Emmaus London", in Mi-Cha Flubacher, Catherine Diederich \& Philipp Dankel (Eds.), New perspectives in empirical linguistics: Studies from young researchers in Switzerland. Bulletin Suisse de Linguistique Apliquée, 104, 2016, pp. 9-26.

Chapter 6 (Section 6.2.2) is derived in part from Maria Rosa Garrido, "Language socialisation and muda: The case of two transnational 


\section{xvi Acknowledgements}

migrants in Emmaus Barcelona”, in Rosina Márquez Reiter and Luisa Martín Rojo (Eds.), Special Issue: Experiences of speakerhood: Migrant speakers' battles for inclusion in traditionally monolingual and bilingual context, International Journal of the Sociology of Language, 257, 2019, Berlin, De Gruyter, pp. 137-163. I would like to thank the three special issue editors, and the anonymous reviewers, whose feedback was very helpful in further shaping the ideas in this book.

\section{Reference}

Calacci, E. (2020). History Unclassified: On Acknowledgements. American Historical Review, https://doi.org/10.1093/ahr/rhz938 


\section{Language, Discourse and Transnationalism in a Social Movement}

\subsection{Emmaus as a Holistic Social Movement}

My first contact with Emmaus dates back to 2008 at a communal lunch in a refectory-style dining room in Barcelona ${ }^{1}$ bustling with chatter in different languages among over 30 people of different social backgrounds, geographical origins and age groups. I could not help but wonder: what brings all these diverse people together at this table? The answer lay in the painting of Abbé Pierre (Henri Grouès, 1912-2007) presiding over us. This image symbolises the origins of the solidarity movement that this French working priest founded in a similar community of ragpickers on the outskirts of post-war Paris. Immediately beneath the Abbé's portrait, there was an aerial picture of the massive Barcelona demonstrations against the Iraq war in 2003. I imagined that the local ragpickers of Emmaus had participated in these massive mobilisations as had many other Leftist civil society organisations in Catalonia.

Fast forward to June 2009. I was sitting in a similar dining room in the first ever Emmaus community in Neuilly-Plaisance, in the Parisian banlieue. Everything looked familiar there, not only because of Abbé Pierre pictures and quotes but also because of the spatial layout, social diversity and communal routines such as the collective lunch that I was invited to. In this case, the main (but not only) language of interaction during lunch was French. My subsequent visits to four British Emmaus communities as part of this study in 2012 and 2013 revealed further symbolic and organisational commonalities in similar groups elsewhere. Linguistically, English was the main language used in these communities. These ethnographic visits to Emmaus communities in France, the UK and Catalonia showed that the figure of Abbé Pierre seemed to give meaning, structure and legitimacy to the Emmaus project, as part of a transnational imaginary shared by many similar local groups around the world.

Recalling my very first encounter with the Emmaus movement in Barcelona, the question of what united people at that table, and at many similar ones all over the world, boiled down to what was going on right there, right then: everyday communication; that is, people interacting 


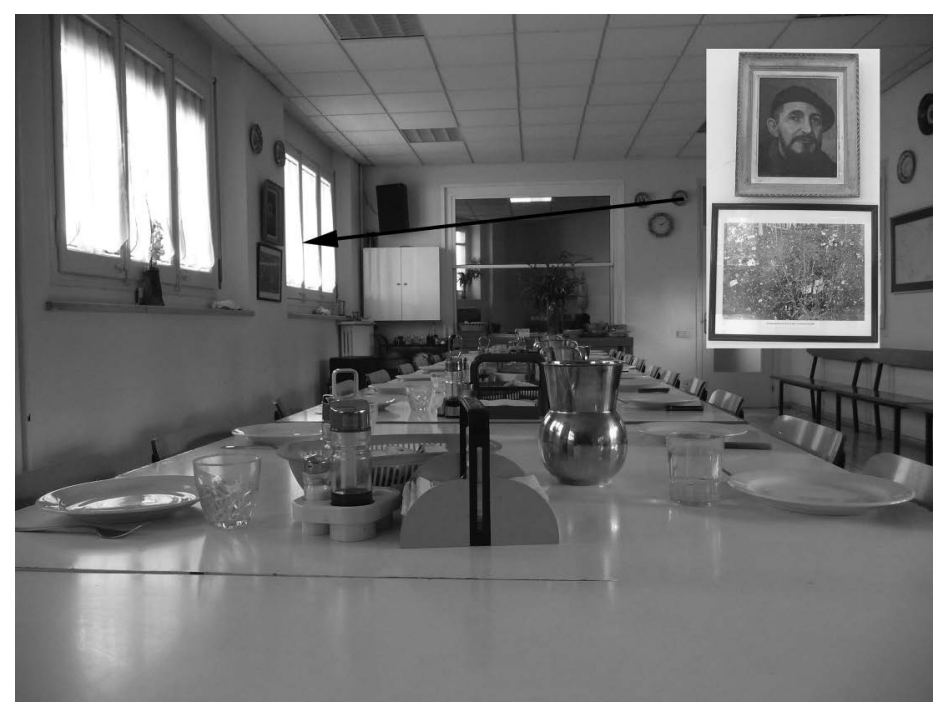

Figure 1.1 Dining room in Emmaus Barcelona, 2012. Pictures taken by Maria Rosa Garrido Sardà, with permission of the community.

with and showing concern for others in ways that (re)create feelings of connectedness. In every single Emmaus community that I have visited, I have invariably been invited for lunch, to share food and conversation with the local members. As a matter of fact, a magazine article on Emmaus Barcelona was entitled "Qui vulgui conèixer Emmaús que vingui a dinar" [Whoever wants to get to know Emmaus, come and have lunch] (2006) and was illustrated with a picture of the community members at the table. This is how visitors and newcomers first hear the stories about Abbé Pierre and the origins of the movement from old-timers (see Chapter 3). This made me wonder about the organisation of individual communities named "Emmaus" and their connections with other groups with the same name and origins, as well as other related social movements and the nation-state apparatus.

While recognising the many commonalities among these communities, my ethnography also foregrounds the differences among local communities in different nation-state contexts. Contrary to my expectations, based on what I had learned from my experiences in Emmaus Barcelona, I did not come across politicised images such as the anti-war demonstration shown in Figure 1.1 in any of the British groups that I visited. To my surprise, I saw pictures of Queen Elizabeth II and Union Jack flags decorating shop windows during the Diamond Jubilee in 2012 (see Figure 6.1) and of the Royal Patron of Emmaus UK, the Duchess of Cornwall, in newsletters. One would never see pictures of royalty 
or national flags in the Barcelona community, vested in alter-globalist discourses against hereditary privilege. Slowly, I came to realise that a social movement is as much about creating transnational sameness as it is about producing social difference locally. Soon enough, I became conscious that one of the key discursive tropes in this movement, that of "solidarity with others", was interpreted and appropriated differently by each local Emmaus group. How do Emmaus communities construct sameness and difference at the same time? What differentiates the local communities? To which discourses and social arenas is "solidarity" connected in local contexts? How do the Emmaus members from different communities talk to each other? These are the some of the questions that I seek to answer in this monograph.

Over the years, I have become fascinated by the holistic nature of the Emmaus movement. Emmaus resembles very few other communitybased initiatives, such as Taizé, L'Arche or Comunità di Sant'Egidio. ${ }^{2}$ Unlike these three examples, and in spite of its early Catholic inspiration, Emmaus is a non-denominational movement where believers and non-believers lead a collective, simple lifestyle to help "those less fortunate" according to the Universal Manifesto of the Emmaus movement (see Appendix 1). Following Bergier (1992), I conceptualise Emmaus as a holistic movement that merges unconditional shelter (accueil in French, acollida in Catalan), cooperative work and social service. The basic pillar of unconditional shelter materialises in local "communities" of "companions" (i.e. residents). An Emmaus community is a social environment in which people from different social backgrounds live and work together for the solidarity mission. According to the Universal Manifesto, any person is welcome regardless of religion, nationality or language, in conformity with the Declaration of Human Rights (UN General Assembly, 1948). The Emmaus philosophy is contrary to traditional charity and challenges the helper/helped dichotomy, as the companions provide support and affection for those who are even worse off.

Companions who live in an Emmaus community collectively engage in voluntary recycling work (Figure 1.2), prioritised by the Universal Manifesto of the Emmaus movement (see Appendix 1) as a "primary means" for the Emmaus mission. This economic activity makes communities self-sustainable, covering the companions' basic needs. The surplus from ragpicking work also allows Emmaus groups to offer local social services to third parties and/or to cooperate with other Emmaus groups and external co-development projects. To maintain their dignity and self-esteem, each person contributes to the recycling process according to their qualifications, skills and preferences. Alberto, a longstanding companion in Barcelona, claimed that "la vida familiar está unida al mundo laboral" [family life and work are united] in the social and labour reinsertion process (interview, 27 March 2012). Unlike the situation in for-profit private companies, companions are asked to work 


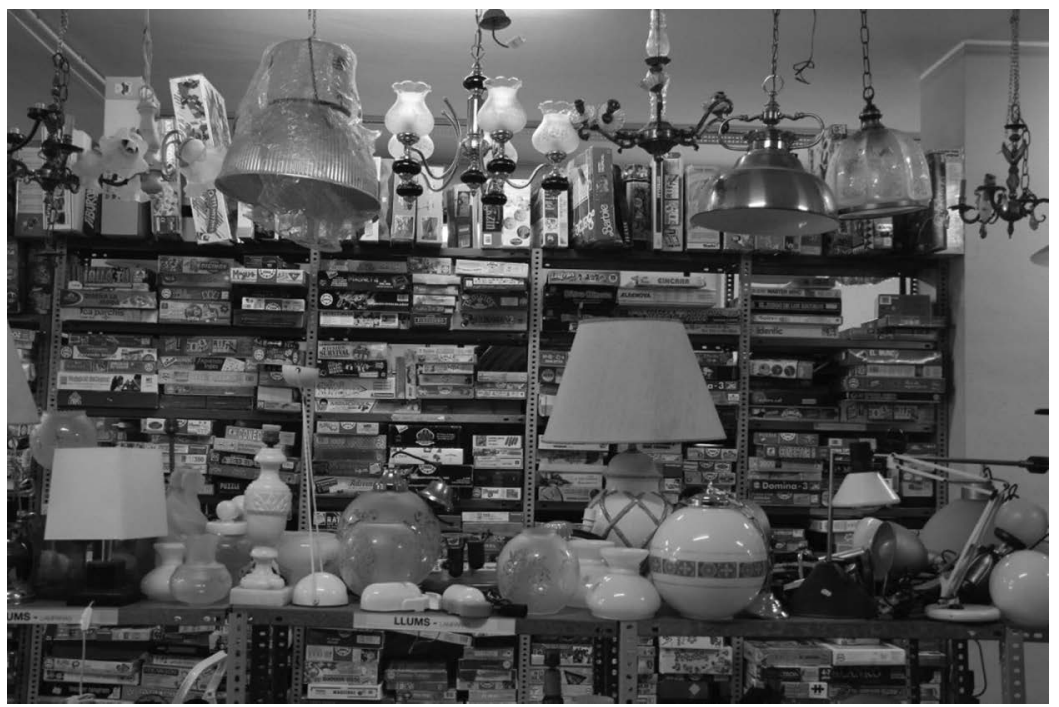

Figure 1.2 Second-hand shop, Emmaus Barcelona. Photo by Ivan Barrios Andelo, reproduced with permission.

according to their ability. Alberto views Emmaus Barcelona as a "community of life and work", linking the Emmaus surrogate "family" to their social entreprise.

Concerning social service in Emmaus, the obligation to "serve first those who suffer most" is not just charity aimed at minimising extreme poverty and homelessness; it is also social protest, reacting to the structural causes of inequality (see Article 6 in the Universal Manifesto, Appendix 1). Abbé Pierre opposed bourgeois charity, which he had witnessed as a child, because it maintains the status quo. In late modernity, recycling labour recreates social belonging in the Fordist period in an altered context in which the nation-state offloads care services to voluntary associations (Muehlebach, 2011). Abbé Pierre disagreed with the Leftist tendency to bypass immediate suffering in order to hasten the revolution. His vision was that the privileged and the underprivileged should join forces for social transformation through Emmaus. The Rule of Emmaus captures this double mission: "In the face of any human suffering, as far as you can, work not only to provide relief without delay but to destroy its causes. Work not only to destroy its causes, but to provide relief without delay" (English version taken from Brodiez-Dolino, 2013, unnumbered page).

Today, Emmaus has more than 350 local groups in 37 nation-states (as of 2015, source: Emmaus International, 2019, https://emmaus-international. org/images/site/menu-secondaire/publications/carte-monde/CARTE_ MONDE_EMMAUS_EN_2015_bd.pdf), which makes it linguistically 
and discursively heterogeneous. My critical sociolinguistic ethnography (Heller, 2011) of Emmaus examines a transnational movement and shared imaginary formed by local communities in different nation-state contexts. This book has two main strands. First, it investigates the situated construction of Emmaus as an imagined community through daily discursive and communicative practices. Second, it takes an ethnographic approach to the discursive appropriations of shared linguistic and discursive resources in different socio-political, economic, historical and sociolinguistic contexts. This monograph is mainly based on intensive ethnographic fieldwork conducted in two Emmaus communities, located in the Barcelona metropolitan area and in Greater London, complemented with visits to the first Emmaus community in Neuilly-Plaisance, the annual Salon Emmaüs in Paris, the Centre Abbé Pierre Emmaüs in Esteville and other European Emmaus communities, as well as the celebration of the 50th Anniversary of the adoption of the Universal Manifesto of the Emmaus movement (May 2019). Besides, the Emmaus movement and the two research sites in my study have been historicised thanks to the Emmaus International Archives located in Roubaix (France).

Emmaus Barcelona is a grassroots community founded in 1980 by young people who were introduced to the movement and its founder at work camps in the 1970s (see Chapter 2). In 2012, it had 14 companions, over 20 volunteers and 3 employees (cook, driver and part-time shop assistant). Decisions were made in community assemblies of companions, four of whom were responsables in a system of primus inter pares. The community led an alternative lifestyle, supported by two second-hand shops and collaboration agreements with the local administration. The financial surplus obtained was employed in co-development projects in Central and South America, in a three-month residential project in the local community (2003-2011) and in a smaller-scale external housing project for unhoused migrants. This group was deeply embedded in the tradition of Social Catholicism, with links to Latin America, and post-'68 ideals now fused into alter-globalist agendas (see Chapter 4).

This community is located in a city on the outskirts of Barcelona in Catalonia (Spanish state), which was predominantly bilingual in two official languages, Spanish as the nation-state language and Catalan as the main historical language. The latter was more present in the city centre where this community was situated. During fieldwork, I documented the emergent bilingual norm in Catalan and Spanish, a form of recipro$\mathrm{cal} /$ passive bilingualism, which gradually overrides the traditional value of Catalan as an intra-language that legitimises the use of Spanish to address those categorised as outsiders, originally castellans (Woolard, 1989) - people from other parts of the Spanish state - as well as transnational migrants today (Pujolar, 2007a). Some migrant languages in the city, notably Tamazight, Wolof, Mandinka and Fula, were present thanks to the residential projects but relegated to backstage spaces together with French and English as lingua francas. 
Emmaus London, on the other hand, is a more recent community, founded in 2007 after a ten-year fundraising campaign under the auspices of Emmaus UK. In March 2012, it had 27 companions who were formerly homeless people; during my fieldwork there, I documented 14 external volunteers. This community had a top-down structure, with nine members of staff (general manager, community leader and deputy community leader, training officer, business manager, retail manager, driver, book keeper and volunteer coordinator) mainly responsible for running the community. In addition, there were three "companion assistants", elected by other companions, who took responsibility for the community overnight. In 2012, their business consisted of two small boutiques and a superstore for second-hand goods. As a young community, Emmaus London was self-sufficient but it did not produce a surplus to support other solidarity projects. This group was dedicated to the labour market reinsertion of homeless people in London, in cooperation with other local organisations (see Chapter 4).

This more recent community is located in a London Borough characterised by ethnic diversity, with a sizeable population of Afro-Caribbean origins, where English remains the dominant language in the linguistic landscape. Emmaus London was English dominant and vested in English banal nationalism. As a consequence, it ideologically erased the multilingual repertoires of some companions. Although it was one of the British communities with a higher percentage of Black and Minority Ethnic (BME) companions, it was composed of a majority of White British English speakers during fieldwork. This was a result of state regulations not to accept those without leave to remain in the UK and the requirement for Housing Benefit for most companions, in line with the practices of other homeless charities. Fluent English was an unwritten requirement to apply for a companion spot and to become accepted by the other companions.

Having introduced Emmaus as a holistic movement, I will now discuss the relevance of social movements today and re-formulate the ethnographic issues presented above into three guiding research questions for this monograph. These questions concern the social, cultural and linguistic significance of community building and maintenance, at a local level and in the wider movement, exploring socioeconomic transformations in late modernity.

\subsection{Investigating Sociolinguistic Articulation across Borders}

Social movements have attracted renewed academic interest, with increasing numbers of research projects being undertaken and courses taught, since the Occupy movements and Arab spring revolutions in 2011. In view of the global political and economic transformations that 
have taken place, this monograph explores the ways in which language and discourse have reconfigured a post-war social movement in the early 21st century. This critical sociolinguistic ethnography explores socioeconomic issues in transnational formations located in post-welfare nation-states at a sociohistorical juncture of neoliberal offloading and economic crisis. In particular, it presents a recent ethnographic study of language in Emmaus from a transnational perspective, contributing to the published French-language literature on Emmaus in sociology (e.g. Carrel \& Eme, 2007), history (e.g. Brodiez-Dolino, 2008) and economics (e.g. Ambroisine, 2014), mainly focusing on the context of France.

Most sociological and anthropological studies of social movements, international agencies and non-governmental organisations (NGOs) pay little or no attention to language, making only passing comments in this respect (e.g. Gatt, 2018). In sociolinguistics, transnational social movements are lesser-studied sites which are nevertheless of key importance in investigating communicative, linguistic, semiotic and interdiscursive aspects of contemporary interconnection between arenas of action (Gal, 2003). To date, there have been few ethnographic studies of how discourse and language shape transnational social movements, allowing the circulation of ideas, discourses, narratives and, to a lesser extent, people. McElhinny (2010) called for more detailed studies that explore civil society movements and organisations from a linguistic anthropological perspective (but see Codó \& Garrido, 2014; Del Percio, 2016; Gal, 2007; Kahn \& Heller, 2006; Martín Rojo, 2016; Muehlmann \& Duchêne, 2007; Pujolar, 2007a; Tesseur, 2017). Codó recently called for more research into "the internal linguistic diversity of these [nongovernmental] organisations and how it is constructed, especially taking into account that many of them are transnational organisations" (2018, p. 478). This monograph, therefore, contributes to the growing body of literature on language in civil society, providing a perspective on the interplay between local, national and transnational constructions of language within a social movement.

Social stratification and categorisation processes are exposed and made explicit, even verbalised, in times of social change (Heller, 2011). Transnational movements must respond to local realities arising from a global economic recession that has diminished the size and role of welfare states and has increased neoliberal control over the unemployed, unhoused and undocumented (see Chapter 4; Gilbert, 2004; Harvey, 2005). Within the movement, I document the evolution of Emmaus following the death of its founder in 2007 and the continuation of two historical ideological and discursive trends in the movement (see Chapter 2; Brodiez-Dolino, 2008). These factors make it especially interesting to study Emmaus at this particular historical moment. In the light of these developments, the two communities investigated were reflexive about their construction of an Emmaus collective identity in situated events. 


\section{Language, Discourse and Transnationalism}

In this respect, community assemblies and meetings were a focal site in my fieldwork (see Section 1.4) to document this reflexivity and the negotiation of identities at this socio-historical juncture.

In my ethnography, I analyse how a social movement is based on relations of communication (with multilingual resources) among heterogeneous localities that share new forms of post-national allegiances. Transnational tropes do not exist in a vacuum but are localised in specific historical, discursive and socio-political nation-state contexts that become the first source of difference between Emmaus communities. More specifically, I sought to understand, first, how similar semiotic, communicative and discursive practices in the local communities I visited created sameness across multiple, heterogeneous groups. I was also intrigued by the other side of the coin, namely, how difference was produced locally, because each and every Emmaus community was unique and not an exact copy of the others. The appropriations of the "solidarity" mission interacted with various local discourses in Emmaus groups situated in different nation-states. Analysing the two sides of the same coin allowed me to document social inclusion and exclusion through legitimate linguistic and discursive resources in the everyday practices of the two communities.

In view of these considerations, the following research questions guided my ethnographic research on Emmaus.

1 How is sameness (re)produced in multiple communities of practice belonging to the transnational Emmaus movement? Which discursive, narrative, semiotic and linguistic resources bind different Emmaus communities together across borders?

2 How is the Emmaus movement configured in each local Emmaus community? In what ways does the Emmaus imagination intersect with local sets of discourses and become appropriated in national sociolinguistic regimes?

3 What are the social and material consequences of these linguistic and discursive local configurations of Emmaus? How do language and discourse shape people's access, participation and positioning in the local communities and the movement?

My first research question looks into the discursive (re)production of Emmaus as a transnational imagined community formed by hundreds of communities located in different geopolitical, nation-state and local contexts. Transnational imagination seems to unite multiple, heterogeneous localities under a single transnational community of sentiment and readership, one that is capable of shared action (Anderson, 1983; Appadurai, 1996, p. 8). This question considers the textual, semiotic and communicative practices that bind different communities within a common Emmaus identity across borders. As we shall see, the main 
elements of this process are the (re)tellings of the founding story, the appropriation of the Universal Manifesto of the Emmaus Movement, the semiotic representations of Abbé Pierre and participation in community assemblies. French, Spanish and English emerge as lingua francas for communication across national and linguistic borders in the movement.

My second research question explores the intersections between the transnational Emmaus imagination, specific nation-state regimes and different discursive arenas, including other social movements, resulting in local genealogies of discursive justification. Transnational interdiscursive devices interact with a set of sedimented traditions, terms and discourses in any locality (Gal, 2003). My aim in this study is to determine which discourses on language, religion, migration and economy, among others, link local Emmaus communities with other social formations, both nationally and transnationally. A central concept to understand the intersection of different discursive trajectories and formations is that of clasp (Gal, 2007), a semiotic or speech element that is repeated in two different discursive arenas and recognised as the same cultural object but which serves different interests and functions in the different arenas (see Section 4.1). Crucially, I will consider the extent to which the national is a component of transnational formations, focusing on local sociolinguistic regimes that contribute to the national project in tension with post-national ideologies of language for communication in the broader Emmaus movement.

My third question concerns the social and material consequences of the linguistic and discursive appropriations of Emmaus concerning people's access to and forms of participation in the local communities and the broader movement. I will focus on individuals who do not speak the local languages and on social activists in alter-globalist networks across linguistic borders. There are visible tensions regarding the discursive appropriations of unconditional welcome and social justice, especially with regard to undocumented migrants, between different ideological trends represented by the two focal communities in my ethnography. Besides, language as practice and as ideology (Heller, 2007) shapes processes of gatekeeping, socialisation, participation and geographical/social mobility in Emmaus. National linguistic regimes, ranging from a monolingual norm in England to an emerging bilingual norm in Catalonia, determine access to Emmaus London and full participation in Emmaus Barcelona. This observation contradicts celebratory discourses of multilingualism and mobility in transnational formations, since some companions are marginalised because of their insufficient communicative and linguistic capital.

\subsection{Critical Ethnographic Sociolinguistics}

This study is mainly grounded in critical ethnographical sociolinguistics, given that I was trained in sociolinguistics, linguistic anthropology 


\section{0}

and applied linguistics. I have drawn on the literature of other disciplines such as history, sociology and anthropology of social movements and NGOs, as well as of labour and religion, as an interested and relatively well-informed non-specialist. It is my hope that this book will be relevant and accessible to those from outside critical sociolinguistics and linguistic anthropology, including activists in social movements.

This research is inspired by post-structuralist and critical social theories, which conceive of ideas and identities as discursively negotiated, (re)produced, naturalised and transformed in social interactions which form part of historical, political and economic processes. In fact, linguistic practices are constitutive of broader social practices that construct social reality and thus, in accordance with Blommaert, "sociolinguistics should be the study of language in order to gain an understanding of society, not a reduction of society into linguistic structure" (2007, p. 3). Therefore, we need to move beyond purely linguistic analyses that focus on language structures in situated interactions. This approach requires post-structuralist concepts that do not construct language, culture and identity as bounded, fixed and abstract entities. In the present study, therefore, I adopt a critical sociolinguistic and ethnographic lens to explore social transformations through linguistic and discursive practices under the conditions of late modernity.

The new sociolinguistics of multilingualism (Martin Jones \& Gardner, 2012) is concerned with concrete linguistic resources that are mobilised in situated interactions linked to the intensified mobilities of people, capital, objects, images and discourses around the globe. The two main developments in sociolinguistics have been the shift from stability to mobility (Heller, 2011), "language on the go", and that from linguistically defined objects to actual linguistic resources deployed in real contexts (Blommaert, 2010). Language configures, and is reconfigured in, new patterns of post-national activity, identity and organisation that destabilise the link between named languages and a stable (national or ethnic) community (Pujolar, 2007b). Mobile people often have truncated linguistic repertoires combining "bits and pieces" of literacy and linguistic resources connected to different named languages in ways that reflect their transnational trajectories (Blommaert \& Backus, 2011). Multilingualism is now taken as the norm rather than the exception to be explained in nation-state unified linguistic markets (Bourdieu, 1991). The mobility of people entails the re/territorialisation of linguistic resources across geographical and social spaces in new forms of social stratification. These spaces ascribe different values to linguistic resources and thus construct social inequalities among the resources and, most importantly, among the people who mobilise them.

In late modernity, post-national processes such as migration, ICT or international organisations have challenged the modernist ideologies of language as a national symbol and the discursive monopoly 
of nation-states over discourses on bi- and multilingualism (Pujolar, 2007b). Today, multilingual competences are viewed as necessary skills for participation in the new economy, while the official languages are used in social selection processes in state institutions such as schools (e.g. Martín Rojo, 2010) or immigration offices (e.g. Codó, 2008a). People increasingly communicate and work in environments that do not form part of the nation-state project of cultural and linguistic commonality. And this is equally true of social movements and NGOs in global civil society (Keck \& Sikkink, 1998). In this respect, Muehlemann and Duchêne (2007) claim that the displacement of the nation-state in the discursive production of multilingualism has given rise to international organisations such as UNESCO and NGOs such as Linguapax as primary sites of discursive production about multilingualism at a supranational level.

Critical ethnographic sociolinguistics is fundamentally interested in linking local practices to wider social and ideological processes in order to reveal social stratification and exclusion. In response to Hymes' early call for an ethnography of speaking to account for the origins and foundations of inequality among speakers (1962), there emerged a concern with symbolic and linguistic aspects of power, domination and global political economy, partly informed by Marxist ideas (Del Percio, Flubacher, \& Duchêne, 2017; Gal, 1989). Such a critical approach to language should explain, in ethnographic terms, the processes of (de) valuation of linguistic resources, as well as their production, circulation and consumption at specific socio-historical junctures and in specific localities. This sociolinguistics of multilingualism is concerned with the uneven access to linguistic resources and their distribution in ways that create socially and culturally salient distinctions among multilingual actors within a larger system of inequality and difference. Language, thus, emerges as a form of symbolic capital that is convertible to social and economic capital under certain conditions (Bourdieu, 1977).

Neoliberalism, involving an extension of the logic of the market to public and private spheres, is opening up new discursive spaces in civil society as a centre of opposition, but not necessarily as an alternative to the hegemonic system (Harvey, 2005). The neoliberal reduction of public budgets has eroded Keynesian welfare states, moving towards a mixed economy of welfare (Gilbert, 2004), with public institutions, private companies and non-profit organisations as partners in the provision of welfare services. The neoliberal organisation of social welfare increasingly enables "people to work and the voluntary sector to assume an expanded role in providing social protection" (Gilbert, 2004, p. 16). This model is market-oriented in that it promotes labour force participation and individual responsibility instead of income support. The shift from the social welfare state to the enabling state has brought about the fragmentation of governmentality into a multitude of markets 


\section{Language, Discourse and Transnationalism}

(Inda, 2006). Foucault's concept of governmentality (1991) refers to the (re)shaping, regulation and management of the conduct of individuals or populations through centralised surveillance and control for specific ends or goals. Governmentality is embedded not only in the activities of state institutions but also in "multiple networks of actors, organizations, and entities that exercise authority over individuals and populations" (Inda, 2006, p. 3), including NGOs, in ways that produce compliance and even agency on the part of the objects of governmentality, namely people and institutions.

This neoliberal logic produces specific subjectivities that affect the ways in which people exert control and shape their own linguistic conduct and repertoires to accumulate linguistic "skills" and capital that are valorised in competitive markets, mainly education and labour. Following Martín Rojo and Del Percio (2019), we should explore how this form of governance affects the ways in which language and communication are conceived, used and regulated and how governmentality is constructed, reproduced and disseminated, but also contradicted and resisted, through discourse and subjectivities. Concerning the latter, ethnography allows us to detect critical positions and practices towards neoliberalism (Martín Rojo \& Del Percio, 2019, p. 21). Social actors can try to avoid the (self-)management of conduct, including language and communication, by acting differently.

This resistance, however, cannot be individual, but requires the construction of an alternative discourse and another rationality, of new hegemonies that help create new subjectivities. In this respect, new social movements can contribute by advancing new models of subjectivity, such as those of cooperative subjects (see Martín Rojo, in preparation), in contrast to the entrepreneurial model that demands continual self examination and improvement.

(Martín Rojo \& Del Percio, 2019, p. 21)

Language and communication intersect with all-encompassing forms of power. Under the current neoliberal conditions, we have seen that social control is exercised top-down not only by the nation-state but also by social institutions and individuals who manage their own and others' conducts. Power is a form of practice that is historically contingent and socially embedded, since inequalities emerge from slow, translocal processes. Braudel's longue durée history (1958) necessarily comprises moments lived by people but it is not just the sum of those parts, since it also captures slower processes that are beyond the reach of individuals. Linguistic phenomena are constitutive of longue durée social phenomena such as nation-building, processes of student selection or the naturalisation of foreigners. Giddens' structuration theory (1984) links individual events or interactions to durable, institutionalised constraints 
on what happens in each concrete event. Discourse is also a resource onto which people project and pursue their interests and exercise power on others. It develops over time and across spaces in ways that are empirically observable through interconnected sites marked by the trajectories of participants and of resources regulated there (Heller, 2011, p. 11). Blommaert $(2001$, p. 7) calls for a materialistic approach to power in which the social formations involved in the (re)production of power are ethnographically documented in more detail, with accounts of their practices, the reasons for their use and where they come from.

In critical sociolinguistic ethnography, "the challenge, then, is to capture both the ways in which things unfold in real time, and the ways in which they sediment into constraints that go far beyond the time and place of specific interactions" (Heller, 2011, p. 40). Heller and Duchêne (2012) propose an articulation of genealogy, defined as "the linkages of discourses across time, or how discursive elements are taken up, circulated, reframed and resemiotised", and of history, that is, "accounts of the political, economic, situated, material development of practices" (2012, p. 15). In the present ethnography, I combine a genealogy of discourses documented through participant observation and the broader political economy of language that shapes situated appropriations of discourses in multiple localities at a particular socio-historical moment. My historicising approach to Emmaus addresses the need for "more information [...] on how movement networks evolve over time and how those changes affect patterns of collective action at large" (Diani, 2015, p. 3). As systematic archives of social movement activity are rare and if existing, partial, I adopt a historicising perspective in my multi-sited ethnography to address the evolution of Emmaus.

\subsection{Key concepts}

\subsubsection{Transnational Social Movements}

In this research, I conceptualise Emmaus as a transnational social movement in the above-described emerging neoliberal and global system. Interest in social movements is spurred by activist networks that connect a range of localities and actors who appropriate common values, discourses, practices and information (Vertovec, 2001). My adoption of "transnational" draws from Portes' (2001) three-way distinction between social actors and scales of activity across national borders. The term "international" refers to relations between nation-states, whereas "multi-national" is reserved for large-scale corporations, NGOs (see Pech \& Padis, 2004) or religions whose activities take place in various nation-states. "Transnational activities would be those initiated and sustained by non-institutional actors, be they organised groups or networks of individuals across borders" (Portes, 2001, p. 186). Transnational 
connections will be the main focus of my ethnography, with some attention to the multi-national aspect of NGO institutionalisation.

Although social movements are often said to be fuzzy phenomena without clear boundaries (Rucht, 2017, pp. 39-40), I adopt Pries' definition of a social movement as a "dense, stable, pluri-local and institutionalised framework composed of material artefacts, the social practices of everyday life, as well as systems of symbolic representation that are structured by and structure human life" (Pries, 2001, p. 8). Diani's definition of social movement regards this framework as a process that combines and reproduces "informal networks between a multiplicity of actors that share a collective identity and are engaged in social or political conflict" (1992, in Diani, 2015, p. 1). Social movements are made up of networks of individuals, cultural and socio-political activities, institutional supporters and alternative institutions as well as social movement organisations (often NGOs) and other actors that support its goals (Hassan \& Staggenborg, 2015, p. 341). The notion of social movement communities aims to capture the interactions between heterogeneous political and cultural elements, as well as informal personal networks, which help sustain social movements (Hassan \& Staggenborg, 2015, pp. 340-342). These networks facilitate the socialisation of individuals into specific sets of values (e.g. solidarity) and competences, including language and communication. Emmaus is a loose network of local groups that are dependent on the transnational network, institutionalised through the international secretariat Emmaus International since 1971, and that may also form part of other networks with different goals (Castells, 1996, p. 171).

In this study, I conceive of Emmaus primarily as a transnational social movement formed by multiple local groups organised across national and linguistic borders rather than as a non-governmental organisation (NGO) operating top-down in different nation-states. The term "NGO" encapsulates an enormous diversity of organisational structures and sizes, social functions, ideologies, juridical forms, as well as duration, scope and range of activities. In fact, this type of organisation has generally been defined in terms of what it is not, namely, non-governmental and non-profit, rather than what it actually is. According to Pech and Padis (2004), the three characteristics that distinguish an NGO like Doctors Without Borders or Greenpeace are (1) private institutions which are not the product of an agreement between states, (2) not-forprofit character, which does not rule out economic activities as long as they revert back to their mission, and (3) a social utility cause that seeks to influence state policies. The holistic and multifaceted Emmaus mission does not fit the discrete categorisations of NGOs made in the social science literature. Moreover, local Emmaus groups are independently registered NGOs or charities under state legal frameworks which may be affiliated to Emmaus International and its federations. Besides, the 
descriptor NGO falls short of capturing the actual transnational and informal connections among people and groups and obscures the heterogeneity that exists within a social movement network.

\subsubsection{Community}

Community is a central discursive trope among my study participants and in Emmaus texts such as the Universal Manifesto, as well as a concept that guides my analysis of this transnational formation in this monograph. The concept combines etic and emic perspectives, the local and the transnational, as well as face-to-face interactions and imaginations beyond the here and now. "Community" is an emic concept used by my participants to refer to face-to-face groups of people working for the Emmaus mission locally. The Universal Manifesto of the Emmaus movement (see Appendix 1) entextualises this term in the Preamble to refer to the basic local structure: "To this end, the Communities were set up, working to live and give". The goal of this research is not to compare these communities or to explain how they are locally (re)produced. Rather, I will use these local communities of practice as a window onto (post-)national identities in a transnational social movement that I conceptualise as an imagined community across national, linguistic and ideological borders.

In this book, I will also draw upon "community" as an etic construct to grasp how the transnationally informed repertoire of individual members constructs their belonging to a wider social movement, which is composed of a network of multiple local groups. In Emmaus, there is a consciousness of a transnational "family" of unseen others. The power of the imagination in the fabrication of transnational social spaces and people's biographies inescapably draws on images, ideas and languages that come from elsewhere (Appadurai, 1996). Anderson (1983) suggests that all communities larger than small villages (and I would argue that even those) are, to some extent, sustained by notions of imagined, understood others. Members of a social formation, such as Emmaus, will never know most of their fellow members, yet in their minds there is an image of communion and shared belonging. My theoretical contribution is a conceptualisation of social movements as imagined communities, hence revisiting and expanding Anderson's idea for national formations. I conceptualise social movements as multilingual, discursive communities of belonging in multiple localities in different nation-states.

Anderson's main argument is that national consciousness arises from the shared readership of printed texts in a standard language, as well as later communication forms such as television viewership. Tarrow (2011) offers a reading of the emergence of transnational social movements in the 18th century, such as abolitionism, as linked to the printed press, which created a shared readership across local associations or reading 
circles. My appropriation of the concept of imagined community as applied to Emmaus retains this imagined consciousness of fellow readers of a stock of common texts and discourses. However, this transnational imagined movement challenges the monolingual ideology in national formations, that is, "the primordial fatality of particular languages and their association with particular territorial units" (Anderson, 1983, p. 43). Emmaus is inherently heterogeneous and multilingual by virtue of its cross-border nature and multi-locale network. Anderson's monolingual bias stems from the interaction among a system of relations of production (Fordist-Keynesian capitalism), a technology of communications (print and TV) and unified linguistic markets in a nation-state (see Bourdieu, 1991). In late modernity, the advent of neoliberal capitalism and digital technologies, as well as the increase in geographical mobility, has stretched boundaries beyond the sovereign nation-state and has flexibilised the transnational circulation of resources, including images, narratives and discourses across borders.

Local Emmaus "communities" are the physical sites of my ethnography where I met many of the participants and from where I have traced connections to other Emmaus communities, social movements and public administrations. These are ethnographically analysed as a local community of practice that develops "a shared repertoire of resources: experiences, stories, tools, ways of addressing recurring problems-in short, a shared practice. This takes time and sustained interaction" (Wenger-Trayner \& Wegner-Trayner, 2015, para. 9). According to Wenger (1998), the emergence and maintenance of a community of practice is based on (1) mutual engagement with other members in a range of activities, (2) accountability to the shared mission and taking responsibility for it and (3) the negotiation of a common repertoire which makes history newly meaningful in the here and now. Such a community cannot be narrowly defined in relation to single events and interactions, nor broadly defined as a social aggregate reified by its name.

In fact, a transnational social movement such as Emmaus is a constellation of communities of practice that may not be particularly close to one another, of the same kind or of the same size (Wenger, 1998, p. 127). However, transnational discourses and practices are reproduced and appropriated in local communities, in ways that may or may not be coherent with each other, owing to discursive localisations in sociohistorical, linguistic and political nation-state contexts.

Focusing on the level of communities of practice is not to glorify the local, but to see these processes- negotiation of meaning, learning, the development of practices, and the formation of identities and social configurations- as involving complex interactions between the local and the global.

(Wenger, 1998, p. 133) 
Emmaus as a transnational imagined community intersects with other social formations in specific localities and in my participants' life trajectories. These include, for example, Liberationist Theology in the case of working priests in Barcelona (see Chapter 2). Participation in one social formation might interact with, and even lead to, participation in others. Local Emmaus "communities", i.e. social groups that function as communities of practice, intersect, not without ideological tensions, with Anderson's national formations. The strength of modernist discourses of language differs according to the research context and to the sociocommunicative space analysed (see Chapter 6).

\subsection{An Ethnographic Journey into a Transnational Field}

The complexities and tensions involved in the fashioning of transnational imagined lives and communities through language and discourse in a deterritorialised field "surely cannot be captured by the localising strategies of traditional ethnography alone" (Appadurai, 1996, p. 52). Current ethnographies have moved from the traditional anthropological paradigm of intensive dwelling in a bounded village to "deep hanging out" involving repeated visiting and collaborative work (Rosaldo in Clifford 1997, p. 188) and, crucially, to "a travelling paradigm" which considers the multiple and asymmetrical connections among sites (Burawoy, 2001). The transnational field is not a mere collection of juxtaposed local communities but a network of sites. Hannerz claims that "one must establish the translocal linkages and the interconnections between those and whatever local bundles of relationships which are also part of the study" (2003, p. 206).

In the light of this paradigm shift, I have adopted a multi-sited design (Marcus, 1995) to grasp the circulation and appropriation of a transnational formation across settings that cannot be accounted for ethnographically from a single (bounded) site. Marcus posits "strategies of quite literally following connections, associations, and putative relationships" (1995, p. 97), and I have constructed my multi-sited research following the Emmaus origins story as "a rich source of connections, associations and suggested relationships" (1995, p. 109). This research project also draws on network ethnography (Howard, 2002) to follow the story in/across the networked sites. Emmaus is viewed as a "perceived community" network with nodal organisational structures, events and people (Howard, 2002), which I have identified through participant observation. Assuming Emmaus to be a research field with constituent parts "forces researchers to be aware of the shared and unique features of different organisations that are home to members of an extended ideational family" (Howard, 2002, p. 561). Multi-sitedness allows different points of entry to the social movement through local nodes in the transnational network. 
From the outlook of different sites, divergent visions of globalisation processes emerge (Burawoy, 2001). The present study is mainly based on data that I collected in two Emmaus communities, a primary research site located in a post-industrial city on the outskirts of Barcelona and a secondary site in Greater London, during one year of ethnographic fieldwork (2011-2012) funded by a pre-doctoral research grant at the Universitat Autònoma de Barcelona. These two communities self-identified as belonging to the "Emmaus" movement, as their name clearly indicated, but their different histories suggested that they belonged to different historical periods and trends (Brodiez-Dolino, 2008, see Chapter 2). Their administrative status and affiliations were not known to me at the start of fieldwork. These two sites were also chosen because they were not French-speaking, contrary to the sites in many other previous studies (see Section 1.2). As explained above (Section 1.3.2), this is not an indepth study of a given organisation and it focuses on the two communities as case studies of the transnational imagination, appropriations and relations in a solidarity movement. Given the financial constraints of this study, I could not include any communities outside Europe, especially in Latin America given the interdiscursive clasps in the primary research site (see Chapter 4).

Emmaus Barcelona inspired this research through my two-year ethnography of a residential project for migrants until 2009 (Garrido, 2010) and the action research that we later developed with participants (Garrido \& Oliva, 2015). My sustained engagement in this community was a window onto the transnational connections and local appropriations of the Emmaus movement. After several visits to the UK, I chose Emmaus London as a secondary site because this community was part of the recent institutionalised expansion of Emmaus in the UK and also because of the high concentration of charities for the homeless in their London Borough. The fieldwork there (April-June 2012), made possible thanks to a three-month mobility grant, focused on the discursive articulation of very different nodes within the same transnational movement and the appropriation of this transnational formation in the British charity tradition and English-dominant sociolinguistic order. I have also used illuminating data from visits to other Emmaus sites in the UK and Europe, Emmaus events, and research interviews, as well as personal communication with key social actors not directly related to the two main sites, from 2009 to 2019.

This research design is embedded in the current debate about the trade-off between ethnographic depth and breadth in carrying out fieldwork in different locations. This social movement articulates face-to-face communities, which have long been the object of classic ethnography in Malinowski's tradition and which require "thick description" (Geertz, 1973), with a transnational network that illuminates relationships between the different nodes (Wittel, 2000) to be apprehended through 
multi-sited ethnography (Marcus, 1995). Nevertheless, we might have to accept a compromise between depth and breadth since we cannot learn about local everyday relationships to the same extent in every site. Marcus posits that sites need not all be treated with the same fieldwork practices and research foci, which further justifies the differing weights accorded to my two sites. In fact, "multi-sited ethnographies inevitably are the product of knowledge bases of varying intensities and qualities" (Marcus, 1995, p. 100). The multi-site approach does not set out to compare two independent sites but to investigate discursive phenomena that are transnationally distributed and multiply situated. Hence, my two sites are not, and were not intended to be, pieces of a jigsaw puzzle that are forced into perfect connection with each other (Hovland, 2009).

\subsubsection{Access, Collaboration and Positioning}

The research field is delimited by the ethnographer as a mobile social actor who renegotiates research questions, social identities and linguistic norms across multiple sites and over time (Pérez-Milans, 2012, p. 2). In fact, the researcher's negotiation of access, positioning and collaboration shapes the conditions for data collection and sheds light on the epistemological limitations. The ethnographer is the main interpreter of the social world she is studying. She decides which research tools to use, who to interact with, which threads to follow and which spaces to explore in order to answer her research questions. As a professional outsider, she negotiates her positioning and often inadvertently violates the local social order. These actions become invaluable ethnographic data for understanding how decision making and social interactions work in a specific research site. My own experiences differed greatly between the two main sites, owing to the different ideological agendas and forms of local organisation in the communities as well as the uneven length and depth of my fieldwork in each site.

Given the nature of this transnational research field, I had to negotiate access to my two research sites separately because these organisations are independent and have only weak ties with each other. Although it is time-consuming to negotiate access to multiple sites (Wittel, 2000), it reveals a great deal about local discursive regimes and social processes in the different localities (Pérez-Milans, 2012). In Barcelona, my identity as a committed volunteer teacher and my collaborative research in the residential project weighed in the bottom-up communitarian decision to grant me access. In London, the top-down decision by the staff responded to my academic credentials and my suitability as an "outsider" volunteer. Interestingly, both communities had had experiences with social science researchers, which greatly facilitated my entry.

My access to the Barcelona community as a researcher involved a bottom-up decision-making process. I had mistakenly constructed Rita 


\section{0}

as the only gatekeeper by virtue of her coordinating position in the residential project that I had previously researched. During a meeting with her, I made an explicit request: "el que et volia demanar avui és si podria treballar amb vosaltres per entendre com funciona Emmaús des de dintre" [What I would like to ask you today is whether I could work with you to understand how Emmaus works from the inside] (fieldnotes, 26 July 2011). She asked me for how long I would be with them and if I could work in the mornings. However, Rita could not make the decision on her own. The whole community (that is, all the companions who work and live together) made the decision in their weekly Friday assembly. Their decision was not unprecedented because the community often took in people who wanted to live and work with them for a short period in order to learn about their alternative lifestyle and social economy. Therefore, my ethnographic methodology was close to their preferred model of first-hand experience.

By way of contrast, my access to Emmaus London involved a topdown decision, which did not include companions and foregrounded my role as a researcher and volunteer. In February 2012, I contacted the community through their Facebook page because their email address was not available on their webpage. The gatekeepers were the Community Leader and the General Manager, as the deputy Community Leader explained to me in their absence during my first visit (fieldnotes, 08 March 2012). I had my gatekeeping interview with the Community Leader, Laura, over the phone. I requested to work with them for two or three days a week "to get to know the people and understand everyday life first-hand" (fieldnotes, ibid.). She granted me access without further consultations because of my social role as an academic outsider. Laura was happy to have me because she thought that my presence (as an outsider) would help companions "widen horizons" socially. This community was also familiar with research and in fact, they had recently hosted a PhD student in anthropology. Besides, she believed it was important to bring researchers into charities, to link up with universities "to make known what we do" (fieldnotes, ibid.). Bearing in mind the importance of bottom-up acceptance among companions, I requested permission to present my research project to all the companions and to inform them about the uses of the data and the measures that would be adopted to preserve their confidentiality.

My negotiation of access was inextricably linked to collaboration in exchange for the data collected, which anthropology regards as a gift from participants. Access is "negotiated within an economic frame, on the basis of exchange, it depends on what the ethnographer has to offer" (Wittel, 2000, p. 4). This requires becoming familiar with the valuable resources circulated in the field and offering something that is going to benefit the participants. In Barcelona, I asked Rita about potential collaboration, but she told me not to worry, as we would eventually 
find "something". I was struggling to come up with counter-gifts, but I failed to understand that my ethnographic engagement was sufficient. In London, I offered to teach Spanish since some companions had asked me for classes. The institutional gatekeepers there considered my study important for disseminating their social work with the homeless and positioned me as a privileged volunteer who would socialise with companions and volunteers.

At the same time, and paradoxically, participant observation in the companions' daily activities at Emmaus Barcelona constituted my way of giving back to the community. This community wanted to demonstrate an alternative lifestyle and economic model by example, so my role as a socially committed ethnographer suited their socio-political goals. Along these lines, Alberto, who had been a Community Leader for 31 years, wanted me to "put our experiences into words" because they lacked the literacy skills or the time to do so. On our first day together on the recycling collection truck (fieldnotes, 13 September 2011), Alberto claimed that he was very happy that I had chosen to study Emmaus because "los académicos no suelen venir a las trincheras" [academics do not usually come to the trenches] and he said that he was interested in my work to "apalabrar nuestras vivencias porque nosotros no podemos o no sabemos" [put our experiences into words because we cannot or do not know how to do so]. In fact, I presented my $\mathrm{PhD}$ thesis in a public talk at their local exhibition gallery (April 2015) and at a closed-doors volunteer meeting (June 2015).

My collaboration with Emmaus London consisted in giving weekly Spanish lessons to companions, at their request, and in interacting with (formerly) homeless people during working hours, at the staff's request. Interestingly, all these social actors categorised me as an outsider to the community, as a foreigner and as a privileged volunteer. My identity as a multilingual speaker who had visited other countries was appealing to a group of multilingual and mobile companions who asked me to organise Spanish language classes after work (see Chapter 6). The staff members were interested in recruiting volunteers such as university students or retired professionals who would provide company and conversation to companions and homeless volunteers who came from day centres or shelters. In our first meeting (fieldnotes, 03 April 2012), the General Manager and Volunteer Coordinator warned me that I would sometimes think that they had assigned me to a workplace where I had nothing to do, but I would later realise that I was actually keeping that person company and chatting with her/him.

In order to obtain voluntary and informed consent (American Anthropological Association, 2012), ethnographers must negotiate with potential informants the terms of their participation in the study in a culturally and socially appropriate manner. Ideally, participants' consent should be negotiated throughout the research process as fieldwork 


\section{Language, Discourse and Transnationalism}

conditions change. In practice, however, we must anticipate research procedures before entering the field, which informants can either accept or not, often by means of institutionally approved consent forms. At the beginning of my fieldwork in each site, I informally discussed the research goals, methods, ethics and dissemination with Emmaus members in assemblies. By and large, my informal oral explanations and the companions' questions in workspaces were much more effective than providing them with written documents approved by an ethical review board. I obtained signed consent from all the people whom I interviewed, with the exception of oral consent from migrants in a focus group.

Assemblies posed a challenge to record because it would have been extremely disruptive to obtain individual signed consent from groups of over 20 people for every single recording. I asked participants orally if they would allow me to record before each assembly and reminded them of their right to stop the recorder or to erase parts of my recording. In London, for the same reasons, the staff members who chaired these meetings asked me not to obtain consent from every single person. Instead, I always approached the chairperson beforehand to ask them if I could make my request to obtain oral consent from the participants, which the American Anthropological Association guidelines also views as acceptable (2012). I decided not to record assemblies in London whenever I could not make a public request beforehand. In Barcelona, regular assembly participants signed a single consent form to participate in my study. They regarded ethical review board individual consent procedures as contrary to their collective ethos and my categorisation as an "insider" or "amiga de la casa" [friend of the house] (fieldnotes, 13 September 2011). Standard consent procedures foregrounded our official contractual relationship over the personal collaborative rapport that we had constructed during fieldwork (Garrido, 2020).

\subsubsection{An Ethnographic Toolbox}

During my one-year intensive fieldwork at Emmaus (July 2011-June 2012), and in subsequent visits to communities and interviews with key participants, I drew on a toolbox of methods to gather ethnographic data. The goal of my data collection was to describe and explain the processes and relationships in my field through multiple points of entry the different sites (see Section 1.1) - and types of data. The following types of data allowed me to triangulate the analysis: (a) an extensive body of field notes and fieldwork indexes, which constitutes the departure point for my analysis; (b) audio recordings of assemblies and meetings as key events for the interactional negotiation and reappropriation of subject positions, narratives and discourses; (c) semi-structured and unstructured interviews with key social actors identified through fieldwork, including one focus group; (d) (audio)visual documents produced 
by Emmaus activists, communities and federations as well as media reports and books about the Emmaus movement and (e) still photos that I took as part of the research process.

The cornerstone of my ethnography, participant observation, produced field notes that illuminate emic categories, social relations and socioeconomic activities in which language and discourse play a constitutive role. My intensive fieldwork in Emmaus Barcelona took place from July 2011 to March 2012, and my three-month fieldwork in London was from April to June 2012. At both sites, I participated in cooperative work (i.e. sorting out clothes, helping out in second-hand stores, cooking, cleaning and carpentry), but I was allowed to collect used furniture and clothes on a van only in Barcelona. Besides, I took part in collective meals, meetings with other civil society organisations and local assemblies in the communities. In Barcelona, I also participated in street demonstrations with the community. Intensive fieldwork allowed me to identify key collective events, which I singled out for audio recording. In both local groups, the key events were regular community assemblies and meetings. I also observed public events at which the communities constructed their local Emmaus identities. In addition, collective meals and after-lunch conversations in Barcelona proved to be key discursive sites. I audio-recorded community assemblies at both sites and some public events that Emmaus Barcelona organised. However, I was unable to record collective meals because of background noise and social inappropriateness.

I also conducted interviews (ranging from unstructured to semistructured) with key participants in the social networks associated with the two Emmaus communities. The goal of one-to-one interviews was to gather declarative data on practices, ideologies and values that would illuminate collective identity construction and on their life trajectories, thus providing discursive links with other civil society associations and intersections with Emmaus. Most interviews were conducted in later fieldwork stages so as to identify the key actors and relevant questions through observations and to establish rapport with interviewees (Codó, 2008b). I planned some broad discussion topics that had emerged from my fieldwork without a pre-established order, to allow the interviewees to introduce their own agendas. I started out by asking how they got to know the Emmaus movement and that particular community. Then, I asked about their responsibilities, coexistence and communication in the local group. Finally, I asked some questions about the wider movement, e.g. whether they knew other communities, what differentiated this social movement from others and what united people in Emmaus all over the world.

Interviews provide accounts that are situated performances indexical of the social context in which they are produced: "what a certain kind of person tells another certain kind of person, in certain ways, under 


\section{Language, Discourse and Transnationalism}

certain conditions" (Heller 2008, p. 256). In Barcelona, my 20 interviews with companions (10), volunteers (8) and employees (2) lasted an average of two hours each and were carried out mostly in vacant spaces in the house, such as the dining room, the terrace or the library, but some volunteers invited me to their homes or public spaces such as cafés. The few broad questions that I asked participants gave rise to lengthy narratives that incorporated the participants' own agendas and interests. In London, my shorter period of fieldwork did not afford the same rapport with participants. There, I decided to interview key participants among staff (4) and companions (8) in 45-minute sessions in common spaces where there were often passers-by. The 12 London interviews were semi-structured with a question-and-answer structure. The participants' perception of the interview as a formal, public situation resulted in the performance of institutional selves (Bourdieu, 1987, p. 5) for the recorder despite our confidentiality clause. Thus, the interview data obtained sometimes contradicted or silenced what I had previously been told in informal conversations, mainly concerning criticisms of or loopholes in the rules. In addition to these core interviews, I interviewed people who (had) held a position in Emmaus UK and Emmaus International (4), a Latin American companion in the Spanish state (1) and a focus group with migrants participating in a temporary residential project in Emmaus Barcelona (1). In addition, my understanding of Emmaus was informed by informal, unrecorded conversations with recent volunteers at both sites.

I collected textual and audiovisual materials that participants engaged with or which were discursively linked to the interactions being observed or recorded (Heller, 2008). The aims were to complement my analysis based on observations and to historicise the local communities within the movement. I first analysed institutional documents which had been produced and/or used by the local participants spontaneously and which had circulated across the transnational network. These are internal representations within the transnational movement that include institutional leaflets, community webpages, Emmaus UK newsletters and Emmaus International posters, among others. Faced with the vast size of the library/archive at Emmaus Barcelona, I was greatly assisted by local responsables in selecting relevant materials for this research. Second, I gathered media reports in the local press, documentaries and publications about the movement, both external representations by third parties and grey literature produced by movement participants since Simon's Les Chiffonniers d'Emmaüs (1954). Third, I was granted access to selected documents of the Emmaus International Archives housed at the Archives Nationales du Monde du Travail (Roubaix, France) in the summer of 2019.

Finally, I also produced still photographs as part of the research process to complement my textual descriptions with visual records of 
materiality (Rose, 2007). These pictures are an artefact of my own ethnographic gaze, rather than objective representations of reality (Murdock \& Pink, 2005). I took pictures of spatial relations to capture "the feel of places" (Rose, 2007, p. 247), such as the inter-faith prayer space in Barcelona, and to describe communal arrangements. Moreover, photography was the only means of capturing certain non-textual semiotic symbols that escape textual accounts. These include portraits of Abbé Pierre (see Figure 1.1) and images of a protest nativity scene (see Figure 2.2). Semiotic symbols circulate between sites and have effects on identity construction. Since I could not take pictures of participants owing to the research ethics imperative to protect confidentiality, my photo documentation was guided by people's interactions with semiotic artefacts and objects. In Barcelona, photo shooting of a literally and symbolically decaying palm tree, in collaboration with the founder Rita, became a way of giving back to the community.

\subsection{Structure of the Book}

In this introductory chapter, I have taken an ethnographic journey across different Emmaus communities in order to introduce the holistic movement. I have then highlighted the contemporary relevance of social movements for sociolinguistics and formulated some research questions on the simultaneous production of sameness and difference through language and discourse and its material consequences for participants in terms of access, legitimacy and participation. In this study I will adopt critical ethnographic sociolinguistics in order to answer these questions. The common thread that runs across the following chapters is "solidarity" as a keyword (Williams, 1976) that is differently interpreted according to the cultural, sociolinguistic and socio-political context across space and over time.

Before focusing on the people in the two main communities that I investigated, Chapter 2 will look into the evolution of the interpretations of solidarity in the history of the movement. Drawing on the Emmaus International Archives and historical research, the first section will trace the history of this originally Francophone movement through key events and the movement's fundamental texts, including their translations and their uptake. These have shaped, and have been shaped by, the transnational expansion of Emmaus and the main ideological trends centripetal and centrifugal (Brodiez-Dolino, 2013) - that emerged in the movement. The second section will locate the genesis, evolution and positioning of the two focal communities in this ethnography in the larger history of the movement mainly through interviews, documents and observations. Both communities in my ethnography interpret the solidarity mission through the lens of different faith traditions, namely Protestant work ethics in London and Progressive Catholicism in Barcelona, in 
ways that map onto centripetal and centrifugal trends in the movement respectively.

Once I have situated my two research sites within the institutional transformations and ideological trends of the Emmaus movement, I will focus on the transnational articulation of multiple localities in the movement through the Emmaus founding story in Chapter 3 and on the creation of difference through the socio-political appropriations of this origin story in local communities in Chapter 4.

Chapter 3 will explore how the central value of solidarity with others is constructed in the Emmaus origins story and how it is appropriated in two local communities. This chapter investigates the transnational articulation and socialisation into the Emmaus founding story (Linde, 2009), which narrates the first spontaneous encounter between Abbé Pierre and Georges Legay. The narrative analysis of chronotopes (Bakhtin, 1981) in its Universal Manifesto entextualisation reveals that the "origins" story is intertextual with the Emmaus Biblical parable of renewed hope (Luke 2413-2435). This central text calls for the re-enactment of this encounter between "men" from different social backgrounds in local communities in which the origins story is both retold and embodied through helping others. My ethnographic analysis shows that participants orient to the same cultural chronotope (Agha, 2007) of place-time-personhood in different sites. Some companions tell personal stories of transformation in finding "new reasons to live" that are intertextual with the founding story. Novices' socialisation into the founding story occurs in daily practices, primarily storytelling with the support of semiotic artefacts such as texts, films and portraits.

Chapter 4 will analyse the situated discursive appropriations of the Emmaus mission of solidarity to legitimise the local groups' existence, positioning and activities. It conceptualises the creation of difference in the Emmaus movement through the notion of interdiscursive clasps (Gal, 2007) with bundles of available discourses in different historical, economic and socio-political traditions. Emmaus Barcelona is vested in alter-globalist discourses of anti-capitalism and eco-justice, as exemplified by a residential project for migrants and socio-political activism for migrants' rights and against budget cuts. Solidarity as collaboration among people from different backgrounds legitimises the Barcelona communitarian lifestyle and activism. The London community, by contrast, adheres to discourses of reciprocity and skilling in the Big Society scheme. It mobilises the moral worth of solidarity with others to activate the homeless through workfare and to provide efficient privatised care in lieu of the state. In sum, these local discursive appropriations of the common mission define "those less fortunate" differently, reflected in the unconditional welcome extended to foreigners outside the welfare system. 
After this analysis of the discursive circulation and appropriations of the "solidarity" Emmaus origins story, I will turn to the language ideologies that construct each group's positioning and alliances in the broader movement (Chapter 5) and the local sociolinguistic norms in Barcelona and in London in the light of (linguistic) nationalism (Chapter 6).

Chapter 5 will investigate the role of language ideologies (Woolard, 1998 ) in the negotiation of two local groups' positioning in the broader movement of solidarity. These ideologies orient towards, and combine, different visions of Emmaus as a multi-national of the heart (Pech \& Padis, 2004) and as a transnational social network (Pries, 2001). The values attached to different lingua francas, namely French, Spanish and English, shape the groups' participation and their negotiation of power relations in the transnational movement, especially vis-à-vis France as the symbolic centre. Based on ethnographic data concerning international events and transnational visits, the analysis shows that French is still the main lingua franca in Emmaus and that both communities in the study background language and multilingualism. Emmaus London is vested in ideologies of English as a lingua franca in the movement, whereas the Barcelona community deproblematises having a shared language in transnational encounters. The findings challenge the commonsense expectations of English as the dominant or sole lingua franca in global networks and of multilingualism in social movements.

Chapter 6 will scrutinise how solidarity with others, through the principle of unconditional welcome, is implemented in everyday encounters in two Emmaus communities. It zooms into the everyday construction of banal nationalism, mainly through linguistic nationalism, and looks into the consequences for individuals' access, legitimacy and degree of participation, with a focus on non-standard or additional speakers of the dominant language(s). Linguistic indexes of national belonging largely mediate the incorporation and socialisation into a local node of a transnational social movement. In London, the monolingual norm in English ideologically erased multilingualism. English was naturalised as a gatekeeping device in conjunction with legal constraints such as legal leave to remain in the UK and having recourse to public funding. Elizabeth II's Jubilee celebrations further reinforced English nationalism but were met with resistance by Irish and Scottish members. Emmaus Barcelona was characterised by a bilingual Catalan-Spanish norm which coexisted with an unconscious, double-edged linguistic etiquette triggering a switch into monolingual Spanish with "castellans" and newly arrived migrants. Despite its openness to migrants, this community also relegated multilingual practices to backstage spaces.

Chapter 7 will showcase the main findings in this monograph and consider the broader implications of the situated linguistic and discursive (re)production, appropriation and stratification of a transnational social movement. Emmaus is based on an imagined community made up 


\section{Language, Discourse and Transnationalism}

of ideas, texts and words from elsewhere. It is simultaneously embedded in nation-state regimes of language and discourse, with resulting transnational trends, as well as linguistic ideologies and bundles of discourses in local groups. The consequences of such heterogeneity are apparent in the tensions between the transnational and the national in terms of legitimate languages and solidarity initiatives, which have an impact on access to and participation in local communities. The roles of imagination and discourse are thus split because they can be both emancipatory and disciplinary for participants. Within an emergent "sociolinguistics of transnationalism", the book's conclusions will be contrasted with analyses of other transnational formations in late modernity. Through a running metaphor of utopia, the closing chapter engages in researcher reflexivity and projects the movement into the future, with updates from post-fieldwork developments.

\section{Notes}

1 The two main communities investigated agreed to disclose the name of the movement, which is so unique that it would be hard to anonymise. However, the exact geographical locations of the communities have been blurred (Barcelona and London instead of the actual locations on the outskirts) to maintain anonymity to the largest extent possible. Pseudonyms have been used for the people who have participated in the study, regardless of how well known they are in the Emmaus movement. The methodological procedures were approved by the Ethics Committee on Animal and Human Experimentation of the Universitat Autònoma de Barcelona.

2 The most similar organisation to Emmaus is L'Arche (http://www.larche. org/). This is an international federation of live-in communities, the first of which was founded by Jean Vanier, a disciple of Ghandi, in the French Catholic tradition. At the heart of the L'Arche communities are relationships between people with and without intellectual disabilities. The mission is to provide community-based services for people with disabilities. Since 1964, L'Arche has grown to comprise 145 communities established in more than 40 countries, worldwide. Moreover, it has become inter-faith.

The Community of Sant'Egidio (http://www.santegidio.org/) shares with Emmaus an ecumenical orientation towards the poor. It was founded in 1968 in the eponymous Roman parish, inspired by Franciscan communities, as was the early Emmaus. It is now a transnational, single community recognised by the Roman Catholic Church and present in over 70 states on four continents. Its mission is based on prayer, spreading the Gospels, a commitment to Ecumenism and free, voluntary service to the poor.

The Community of Taizé (http://www.taize.fr/) is often invoked in relation to Emmaus. Its mission has always been that of reconciliation among the various Christian denominations - Catholic, Orthodox and Protestant. It was founded by Roger Schutz to house war victims in 1940, similarly to Abbé Pierre's later opening of an international youth hostel called Emmaus for post-war reconciliation (see Chapter 2). It is a single Christian monastic community in France which attracts numerous people seeking a retreat. Local committees in a number of Christian parishes organise annual youth encounters in Europe. 
1 This chapter draws on the Emmaus International Archives housed in the Archives Nationales $d u$ Monde du Travail (ANMT) in Roubaix (France). For the sake of space and readability, the in-text references will indicate the Archives classification as (ANMT $2000050+$ number of file).

2 The Universal Manifesto was initially translated into French, English and Spanish. In 2009, Emmaus International translated the Universal Manifesto into 21 languages that were spoken in local communities including German, English, Arabic, Basque, Bengali, Bosnian, Danish, Spanish, Finnish, French, Hindi, Indonesian, Italian, Melgache/Malagasy, Dutch, Polish, Portuguese, Romanian, Russian, Swedish, Tamil. (Source: https:// www.emmaus-international.org/en/articles/universal-manifesto.html https://www.emmaus-international.org/en/articles/universal-manifesto. html, 25 July 2019)

3 The first one counts 13 translated editions in 12 languages, including Italian the same year, English (US) and Polish (1955), Greek (1956), Portuguese (Brazil, 1957), German (1958), Japanese (1960) Danish (1963), Swedish (1964) Finnish (1977). The second one was only translated into German and Spanish (1956) and Polish (1958). Source: Mary (2018).

1 The storyworld and interactional world correspond to Silverstein's denotational and interactional texts (Silverstein, 2005), Stasch's narrated chronotope and chronotope of performance (Stasch, 2011) and Bauman's (1986) narrated and narrative events.

2 Bakhtin occasionally uses the terms chronotope and motif as synonyms, as when he uses "chronotope of meeting" interchangeably with "motif of meeting" (p. 97).

3 Alberto's claim is intertextual with Mademoiselle Coutaz's closing sentence from her book Avec les chiffonniers d'Emmaüs (Coutaz, 1970): “Oui, 'Emmaüs', ce n'est pas ce que nous avons fait, mais bien ce qui nous est arrivé" [Yes, "Emmaus" is not what we have done, but rather what has happened to us] (p. 123). Please note that Alberto's formulation is in the present, whereas Mlle Coutaz's is in the past.

1 This movement is not anti-globalist because it presents the global scale as historically unavoidable and desirable. Parenteau (2011) disregards the inclusion of activists who want less globalisation, be it through a reinforcement of nation-state sovereignty or a focus on the local, in altermondialisme. Fougier (2012) discusses the "degrowth" and "deglobalisation" movements in France as ideological challenges to this mouvance.

2 These are all examples of the marché de la vertu [market of virtue], which aims to incorporate humanist and moral principles into commercial exchange. In spite of the stated goal of sustainable development, fair trade and micro-lending "contribuent à créer des relations de marché là où bien souvent il n'y avait pas" [contribute to creating market relations where there were usually none] (Pech \& Padis, 2004, p. 74)

3 The Zapatista movement started with the uprising against the 1994 NAFTA agreements that effectively ended the right to collective land ownership by indigenous populations, then moved on to organise the first altermondialiste meetings in 1996 and, later on, unilaterally applied self-government in autonomous municipalities in Chiapas (Mexico), enabling universal access to healthcare and education and a self-sustained economy based on agriculture. This movement signals a rupture with revolutionary movements of the past and Marxist anti-capitalism thanks to the Amerindian worldview and the close links with the Theology of Liberation, under the authority of the bishop of San Cristóbal de las Casas, 
Samuel Ruiz (1924-2011), who lived and worked with Ramon (featured in my ethnography).

4 Founded in France in 1998, ATTAC is an international organisation that is a pioneer of the alter-globalist movement. They were present at the $1999 \mathrm{Se}-$ attle demonstrations and they also initiated the First World Forum in 2001 with other organisations. It specifically fights for

the regulation of financial markets, the closure of tax havens, the introduction of global taxes to finance global public goods, the cancellation of the debt of developing countries, fair trade, and the implementation of limits to free trade and capital flows.

Source: www.attac.org (Date accessed: 11 August 2019)

5 The Big Society election theme has only been retained in an English policy environment owing to devolution to the other nations, where the Conservatives were not in power after the 2011 election (Alcock, 2012).

1 I have not been able to locate the source of Charles de Gaulle's quote. The staff at the Centre Abbé Pierre Emmaüs Esteville and at the Archives Nationales $d u$ Monde $d u$ Travail have not been able to locate it either.

2 I use "Southern Catalonia" to refer to the Spanish autonomous community of Catalonia and to differentiate it from "Northern Catalonia", which refers to the historically Catalan-speaking region of Roselló (in Catalan)/Rousillon (in French) ceded to France by Spain in 1659. The nation-state border has historically separated the Northern and Southern regions, and this is also true of Emmaus Barcelona.

1 By way of contrast, I documented unhedged discourses of British national pride about the monarchy among English companions after the Jubilee celebration weekend. When I asked about their weekend, a group of male English companions who were smoking outside the house told me that the monarchy is unique to "us Brits". Edward added that he only enjoyed it because it is "something that Americans don't have" and would love to have, to which other companions added that it is about the "historic lineage" of the institution in spite of some changes (fieldnotes, 6 June 2012).

2 Spanish is commonly called "Castilian" in Catalonia, indexing the geographical area where it originated (Castile). In some parts of the Spanish state, it is considered a language "from somewhere" specific rather than a public, anonymous language "from nowhere" (Woolard, 2016, p. 39). I will use both terms without distinction in this chapter even though the term Spanish could also be used for a global lingua franca, as in Chapter 5.

3 In Catalonia, "moro" is commonly used as a pejorative term for persons from North Africa or for Arabs. Massin reappropriated and revalorised this stigmatised term by self-consciously referring to himself and Imazighen using this label. Companions like Esther followed suit. 


\section{References}

Agha, A. (2007). Recombinant Selves in Mass Mediated Spacetime. Language and Communication, 27, 320-335.

Ambroisine, J. (2014). Les Communautés Emmaüs en Europe. Revue Internationale de l'Économie Sociale, 332, 74-92.

American Anthropological Association (2012). Principles of Professional Responsibility. Retrieved from: http://ethics.americananthro.org/category/ statement/ [31st March 2018]

Anderson, B. (1983). Imagined Communities: Reflections on the Origin and Spread of Nationalism (3rd ed.). London: Verso.

Appadurai, A. (1996). Modernity at Large: Cultural Dimensions of Globalization. Minneapolis: University of Minnesota Press.

Bakhtin, M. (1981). Forms of Time and the Chronotope in the Novel. In M. Holquist (Ed.), The Dialogic Imagination (pp. 84-259). Austin: University of Texas Press.

Bergier, B. (1992). Compagnons d'Emmaüs: Sociologie du Quotidien Communautaire. Paris: Éditions Ouvrières.

Blommaert, J. (2001). The Debate Is Open. In J. Blommaert (Ed.), Language Ideological Debates (pp. 1-38). Berlin and New York: Mouton de Gruyter.

Blommaert, J. (2007). Sociolinguistic Scales. Intercultural Pragmatics, 4(1), $1-19$.

Blommaert, J. (2010). The Sociolinguistics of Globalisation. Cambridge: Cambridge University Press.

Blommaert, J., \& Backus, A. (2011). Repertoires Revisited: "Knowing Language" in Superdiversity. Working Papers in Urban Language and Literacies 67. Retrieved from: http://www.kcl.ac.uk/sspp/departments/education/ research/ldc/publications/workingpapers/67.pdf [8th September 2014]

Bourdieu, P. (1977). The Economics of Linguistic Exchanges. Social Sciences Information, 16(6), 645-668.

Bourdieu, P. (1987). The Biographical Illusion. Working Papers and Proceedings of the Center for Psychosocial Studies, 14. Chicago, IL: Center for Psychosocial Studies.

Bourdieu, P. (1991). Language and Symbolic Power. Cambridge: Polity Press.

Braudel, F. (1958). Histoire et Sciences Sociales: La Longue Durée. Annales. Histoire, Sciences Sociales, 13(4), 725-753.

Brodiez-Dolino, A. (2008). Emmaüs et l'Abbé Pierre. Paris: Les Presses de Sciences Po.

Brodiez-Dolino, A. (2013). Emmaus and the Abbé Pierre: An Alternative Model of Enterprise, Charity and Society. Paris: Les Presses de Sciences Po.

Burawoy, M. (2001). Manufacturing the Global. Ethnography, 2(2), 147-159.

Carrel, M., \& Eme, B. (2007). Les Communautés Emmaüs dans un Monde Incertain: Les Enjeux d'un Renouvellement des Pratiques Communautaires. Paris: Editions des Communautés Emmaüs.

Castells, M. (1996). The Rise of the Network Society, The Information Age: Economy, Society and Culture Vol. I (2nd ed.). Cambridge, MA and Oxford: Blackwell.

Clifford, J. (1997). Spatial Practices: Fieldwork, Travel and the Disciplining of Anthropology. In A. Gupta \& J. Ferguson (Eds.), Anthropological Locations: 
Boundaries and Grounds of a Field Science (pp. 185-222). Berkeley and Los Angeles: University of California Press.

Codó, E. (2008a). Immigration and Bureaucratic Control: Language Practices in Public Administration. Berlin: Mouton de Gruyter.

Codó, E. (2008b). Interviews and Questionnaires. In L. Wei \& M. Moyer (Eds.), The Blackwell Guide to Research Methods in Bilingualism and Multilingualism (pp. 158-176). Oxford: Blackwell.

Codó, E. (2018) Language Awareness in Multilingual and Multicultural Organisations. In P. Garrett \& J. M. Cots (Eds.), The Routledge Handbook of Language Awareness (pp. 467-481). Abingdon and New York: Routledge.

Codó, E., \& Garrido, M. R. (2014). Shifting Discourses of Migrant Incorporation at a Time of Crisis: Understanding the Articulation of Language and Labour in the Catalan Non-governmental Sector. In E. Codó \& M. PérezMilans (Eds.), Multilingual Discursive Practices and Processes of Social Change in Globalizing Institutional Spaces. Special Issue of International Journal of Multilingualism, 11 (4), 389-408.

Del Percio, A. (2016). The Governmentality of Migration: Intercultural Communication and the Politics of (Dis)placement in Southern Europe. Language and Communication, 51, 87-98.

Del Percio, A., Flubacher, M. C., \& Duchêne, A. (2017). Language and Political Economy. In O. García, N. Flores, \& M. Spotti (Eds.), The Oxford Handbook of Language and Society (pp. 55-75). Oxford: Oxford University Press.

Diani, M. (1992). The Concept of Social Movement. Sociological Review, 40, 1-25.

Diani, M. (2015). Social Movements and Networks. In G. Ritzer (Ed.), The Blackwell Encyclopedia of Sociology (pp. 1-4). Oxford: Blackwell.

United Nations. (2019). UN Declaration of Human Rights: https://www.un.org/ en/universal-declaration-human-rights

Foucault, M. (1991). Governmentality. In G. Burchell, C. Gordon, \& P. Miller (Eds.), The Foucault Effect: Studies in Governmentality (pp. 87-104). Chicago, IL: University of Chicago Press.

Gal, S. (1989). Language and Political Economy. Annual Review of Anthropology, 18, 345-367.

Gal, S. (2003). Movements of Feminism: The Circulation of Discourses about Women. In B. Hobson (Ed.), Recognition Struggles and Social Movements: Contested Identities, Agency and Power (pp. 93-120). Cambridge: Cambridge University Press.

Gal, S. (2007, December). Circulation in the "New" Economy: Clasps and Copies. Paper presented at the 106th Meeting of the American Anthropological Association, Washington, DC.

Garrido, M. R. (2010). "If You Slept in Catalunya You Know That Here It's a Paradise': Multilingual Practices and Ideologies in a Residential Project for Migrants”. Unpublished MA Thesis: Universitat Autònoma de Barcelona.

Garrido, M. R. (2020, 21 January). Negotiating Ethics: Between Contractual Forms and Collaborative Reflection [Blog post]. Retrieved from: https:// www.chroniquesduterrain.org/questionner/negotiating-ethics-betweencontractual-forms-and-collaborative-reflection [5th February 2020]

Garrido, M. R., and Oliva, X. (2015). A Multilingual, Collaborative and Functional Literacy Approach to Catalan Language Learning in a Voluntary 
Settlement Project. In J. Simpson \& A. Whiteside (Eds.), Adult Language Education and Migration: Challenging Agendas in Policy and Practice (pp. 94-106). London: Routledge.

Gatt, C. (2018). An Ethnography of Global Environmentalism: Becoming Friends of the Earth. New York and Oxon: Routledge.

Geertz, C. (1973). Thick Description. In C. Geertz (Ed.), The Interpretation of Cultures (pp. 3-32). New York: Basic Books.

Giddens, A. (1984). The Constitution of Society: Outline of the Theory of Structuration. Berkeley: University of California Press.

Gilbert, N. (2004). Transformation of the Welfare State: The Silent Surrender of Public Responsibility. Oxford: Oxford University Press.

Hannerz, U. (2003). Being There... and There... and There!: Reflections on Multi-site Ethnography. Ethnography, 4(2), 201-216.

Harvey, D. (2005). A Brief History of Neoliberalism. Oxford: Oxford University Press.

Hassan, H. M., \& Staggenborg, S. (2015). Movements as Communities. In D. Della Porta \& M. Diani (Eds.), The Oxford Handbook of Social Movements (pp. 340-354). Oxford: Oxford University Press.

Heller, M. (2007). Bilingualism as Ideology and Practice. In M. Heller (Ed.), Bilingualism: A Social Approach (pp. 1-22). Houndsmills, Basingstoke, Hampshire and New York: Palgrave Macmillan.

Heller, M. (2008). Doing Ethnography. In L. Wei \& M. Moyer (Eds.), The Blackwell Guide to Research Methods in Bilingualism and Multilingualism (pp. 249-262). Oxford: Blackwell.

Heller, M. (2011). Paths to Post-nationalism: A Critical Ethnography of Language and Identity. New York: Oxford University Press.

Heller, M., \& Duchêne, A. (2012). Pride and Profit: Changing Discourses of Language, Capital and Nation-state. In A. Duchêne \& M. Heller (Eds.), Language in Late Capitalism: Pride and Profit (pp. 1-21). New York and Abingdon: Routledge.

Hovland, I. (2009). Follow the Missionary: Connected and Disconnected Flows of Meaning in the Norwegian Mission Society. In M. A. Falzon (Ed.), Multisited Ethnography: Theory, Praxis and Locality in Contemporary Research (pp. 135-148). Farham: Burlington.

Howard, P. N. (2002). Network Ethnography and the Hypermedia Organisation: New Media, New Organisations, New Methods. New Media and Society, 4(4), 550-574.

Inda, J. X. (2006). Targeting Immigrants: Government, Technology, and Ethics. Oxford: Wiley-Blackwell.

Kahn, E., \& Heller, M. (2006). Idéologies et Pratiques du Multilinguisme au Québec: Luttes et Mutations dans un Site de la Nouvelle Économie. Langage et Société, 118, 43-63.

Keck, M., \& Sikkink, K. (1998). Activists beyond Borders: Advocacy Networks in International Politics. Ithaca, NY: Cornell University Press.

Linde, C. (2009). Working the Past: Narrative and Institutional Memory. Oxford: Oxford University Press.

Marcus, G. E. (1995). Ethnography in/of the World System: The Emergence of Multisited Ethnography. Annual Review of Anthropology, 24, 95-117. 
Martin-Jones, M., \& Gardner, S. (2012). Introduction: Multilingualism, Discourse and Ethnography. In S. Gardner and M. Martin-Jones (Eds.), Multilingualism, Discourse, and Ethnography (pp. 1-15). New York: Routledge.

Martín Rojo, L. (2010). Constructing Inequality in Multilingual Classrooms. Berlin: Mouton de Gruyter.

Martín Rojo, L. (Ed.) (2016). Occupy: The Spatial Dynamics of Discourse in Global Protest Movements. Amsterdam and Philadelphia, PA: John Benjamins.

Martín Rojo, L., \& Del Percio, A. (2019). Neoliberalism, Language, and Governmentality. In L. Martín Rojo \& A. Del Percio (Eds.), Language and Neoliberal Governmentality (pp. 1-26). Oxon and New York: Routledge.

McElhinny, B. (2010). The Audacity of Affect: Gender, Race and History of Linguistic Accounts of Legitimacy and Belonging. Annual Review of Anthropology, 39, 309-328.

Muehlebach, A. (2011). On Affective Labor in Post-Fordist Italy. Cultural Anthropology, 26(1), 59-82.

Muehlmann, S., \& Duchêne, A. (2007). Beyond the Nation-state: International Agencies as New Sites of Discourses on Bilingualism. In M. Heller (Ed.), Bilingualism: A Social Approach (pp. 96-110). Houndsmills, Basingstoke and New York: Palgrave Macmillan.

Murdock, G., \& Pink, S. (2005). Picturing Practices: Visual Anthropology and Media Ethnography. In E. W. Rothenbuhler \& M. Coman (Eds.), Media Anthropology (pp. 149-162). London: Sage.

Pech, T., \& Padis, M. O. (2004). Multinationales du Coeur: Les ONG, la Politique et le Marché. Paris: Seuil.

Pérez-Milans, M. (2012). “Ah! Spain, That's Far away from China”: Reflexividad Metodológica y Movilidad en la Etnografía Sociolingüística Crítica. Spanish in Context, 9(2), 219-243.

Portes, A. (2001). Introduction: The Debates and Significance of Immigrant Transnationalism. Global Networks, 1(3), 181-193.

Pries, L. (2001). The Approach of Transnational Social Spaces: Responding to New Configurations of the Social and the Spatial. In L. Pries (Ed.), New Transnational Social Spaces: International Migration and Transnational Companies in the Early Twenty-first Century (pp. 3-29). London and New York: Routledge.

Pujolar, J. (2007a). African Women in Catalan Language Courses: Struggles over Class, Gender and Ethnicity in Advanced Liberalism. In B. McElhinny (Ed.), Words, Worlds and Material Girls: Language, Gender, Globalisation (pp. 305-348). Berlin: Mouton de Gruyter.

Pujolar, J. (2007b). Bilingualism and the Nation-state in the Post-national Era. In M. Heller (Ed.), Bilingualism: A Social Approach (pp. 71-95). Houndsmills, Basingstoke, Hampshire and New York : Palgrave Macmillan.

Rose, G. (2007). Visual Methodologies: An Introduction to the Interpretation of Visual Materials. London: Sage.

Rucht, D. (2017). Studying Social Movements: Some Conceptual Challenges. In S. Berger \& H. Nehring (Eds.), The History of Social Movements in Global Perspective: A Survey (pp. 39-62). London: Palgrave Macmillan.

Tarrow, S. (2011). Power in Movement: Social Movements and Contentions Politics (3rd ed.). Cambridge: Cambridge University Press. 
Tesseur, W. (2017). Incorporating Translation into Sociolinguistic Research: Translation Policy in an International Non-governmental Organisation. Journal of Sociolinguistics, 21(5), 629-649.

Vertovec, S. (2001). Transnational Social Formations: Towards Conceptual Cross-Fertilization. Paper Presented at Workshop "Transnational Migration: Comparative Perspectives”, June 30-July 1, Princeton University, Princeton.

Wenger, E. (1998). Communities of Practice: Learning, Meaning, and Identity. Cambridge: Cambridge University Press.

Wenger-Trayner, W., \& Wenger-Trayner, B. (2015). Introduction to Communities of Practice: A Brief Overview of the Concept and Its Uses. Retrieved from: http://wenger-trayner.com/introduction-to-communities-of-practice/ [31st March 2018]

Williams, R. (2015 [1976]. Keywords: A Vocabulary of Culture and Society (3rd ed.). Oxford: Oxford University Press.

Wittel, A. (2000). Ethnography on the Move: From Field to Net to Internet. Forum Qualitative Sozialforschung/ Forum: Qualitative Social Research, 1(1), Art. 2. Retrieved from: http://nbn-resolving.de/urn:nbn:de:0114-fqs0001213 [31st March 2018]

Woolard, K. A. (1989). Double Talk: Bilingualism and the Politics of Ethnicity in Catalonia. Stanford, CA: Stanford University Press.

Woolard, K. A. (1998). Introduction: Language Ideology as a Field of Inquiry. In B. Schiefflin, K. Woolard, \& P. Kroskrity (Eds.), Language Ideologies: Practice and Theory (pp. 3-47). Oxford: Oxford University Press.

Abbé Pierre \& Lenoir, F. (2005). Mon Dieu... Pourquoi? Petites Déditations sur la Foi Chrétienne et le Sens de la Vie. Paris: Plon.

Agrikoliansky, É., Filleule, O., \& Mayer, N. (2005). L'Altermondialisme en France: La Longue Histoire d'une Nouvelle Cause. Paris: Flammarion.

Alvey, N. (1995). From Chantry to Oxfam: A Short History of Charity and Charity Legislation. Chichester: Phillimore.

Ambroisine, J. (2014). Les Communautés Emmaüs en Europe. Revue Internationale de l'Économie Sociale, 332, 74-92.

Botey, J. (2011). Capellans Obrers: Compromís de l'Església amb el Món Obrer. Barcelona: Cristianisme i Justícia.

Bretherton, J., \& Pleace, N. (2012). New Growth for Emmaus. Research Report. Centre for Housing Policy, The University of York. Retrieved from: http:// eprints.whiterose.ac.uk/74312/1/Emmauspubformat.pdf [1st April 2018]

Brodiez, A. (2009a). Circulations et Recompositions des Espaces du Politique dans les ONG : Le cas d'Emmaüs. Politique et Sociétés, 28(1), 91-109.

Brodiez, A. (2009b). Entre Social et Humanitaire: Générations Militantes à Emmaüs (1949-2009). Le Mouvement Social, 227(2), 85-100.

Brodiez-Dolino, A. (2013). Emmaus and the Abbé Pierre: An Alternative Model of Enterprise, Charity and Society. Paris: Presse de Sciences Po.

Casañas, J. (1989). El Progressisme Catòlic a Catalunya (1940-1980): Aproximació Històrica. Barcelona: La Llar del Llibre.

Coutaz, L. (1970). Avec les Chiffonniers d'Emmaüs: Peines, Luttes et Joies. Charenton: Editions S.C.E.P.E.S.

Cunningham, H. (1995). God and Caesar at the Rio Grande: Sanctuary and the Politics of Religion. Minneapolis and London: University of Minnesota Press. Filby, L. (2011). Faith, Charity and Citizenship: Christianity, Voluntarism and the 
State in 1980s Britain. In M. Hilton \& J. McKay (Eds.), The Ages of Voluntarism: Evolution and Change in Modern British Voluntary Action. Oxford: Oxford University Press: https://britishacademy.universitypressscholarship.com/view/ 10.5871/bacad/9780197264829.001.0001/upso-9780197264829-chapter-7.

Frey, R., \& Powell, L. A. (2009). Protestant Work Ethic Endorsement and Social Justice Values in Developing and Developed Societies: Comparing Jamaica and New Zealand. Psychology and Developing Societies, 21(1), 51-77.

Gómez Gil, C. (2005). Las ONG en España: De la Apariencia a la Realidad. Madrid: Catarata.

Lefèvre, D. (2001). Les Combats d'Emmaüs. Paris: Le Cherche Midi.

Liogier, R. (2007). L'ONG, Agent Institutionnel Optimal du Champ Religieux Individuo-Globalisé. In K. Rousselet, B. Duriez, \& F. Mabille (Eds.), Les ONG Confessionnelles, Religions et Action Internationale (pp. 263-276). Paris: L'Harmattan.

Löwy, M. (1996). The War of Gods: Religion and Politics in Latin America. London: Verso.

Mary, B. (2018). Emmaus International et son Fondateur l'Abbé Pierre: Bibliographie Multilingue. Unpublished: Emmaus International.

Muehlebach, A. (2009). Complexio Oppositorum: Notes on the Left in Neoliberal Italy. Public Culture, 21(3), 495-515.

Pérez De Mendiguren, J. C., \& Villalba, U. (2013). Los Modelos Organizativos de Traperos de Emaús en el Estado y su Respuesta a la Crisis. REVESCO Revista de Estudios Cooperativos, 113, 150-179.

Simon, B. (1954). Les Chiffoniers d'Emmaüs. Paris: Editions du Seuil.

Simon, B. (1955). Le Poids des Autres. Paris: Editions du Seuil.

Taylor, M. (2002). Government, the Third Sector and the Contract Culture: the UK Experience so far. In U. Ascoli \& C. Ranci (Eds.), Dilemmas of the Welfare Mix: The New Structure of Welfare in an Era of Privatization (pp. 77-108). New York, Boston, MA, Dordrecht, London, Moscow: Kluwer Academic/Plenum Publishers.

Weber, M. (1930). The Protestant Work Ethic and the Spirit of Capitalism. London and New York: Routledge.

Agha, A. (2005). Voice, Footing, Enregisterment. Journal of Linguistic Anthropology, 15 (1), 38-59.

Agha, A. (2007). Recombinant Selves in Mass Mediated Spacetime. Language and Communication, 27, 320-335.

Bakhtin, M. M. (1981). The Dialogic Imagination. (M. Holquist, Ed.). Austin: University of Texas Press.

Barthes, R. (1957). Mythologies. Paris: Seuil.

Bauman, R. (1986). Story, Performance and Event: Contextual Studies of Oral Narrative. Cambridge: Cambridge University Press.

Bemong, N., Borghart, P., De Dobbeleer, M., Demoen, K., De Temmerman, K., \& Keunen, B. (2010). Bakhtin's Theory of the Literary Chronotope Reflections, Applications, Perspectives. Ghent: Gingko Academia Press.

Bergier, B. (1992). Compagnons d'Emmaüs: Sociologie du Quotidien Communautaire. Paris: Éditions Ouvrières.

Blommaert, J., \& De Fina, A. (2016). Chronotopic Identities: On the Timespace Organization of Who We Are. Tilburg Papers in Culture Studies 153.

Cain, C. (1991). Personal Stories: Identity Acquisition and Self-Understanding in Alcoholics Anonymous. Ethos, 19(2), 210-253. 
Coutaz, L. (1970). Avec les Chiffonniers d'Emmaüs: Peines, Luttes et Joies. Charenton: Editions S.C.E.P.E.S.

Davis, J. E. (2002). Narrative and Social Movements: The Power of Stories. In J. E. Davis (Ed.), Stories of Change: Narrative and Social Movements (pp. 3-30). Albany: State University of New York Press.

De Fina, A., \& Georgakopoulou, A. (2012). Analysing Narrative: Discourse and Sociolinguistic Perspectives. Cambridge: Cambridge University Press.

De Fina, A., \& Perrino, S. (2011). Introduction: Interviews vs. Natural Contexts: A False Dilemma. Language in Society.

Ganz, M. (2010). Leading Change: Leadership, Organization and Social Movements. In N. Nohria \& R. Khurana (Eds.), Handbook of Leadership Theory and Practice: A Harvard Business School Centennial Colloquium (pp. 527-566). Boston, MA: Harvard University Press.

Garrett, P. B., \& Baquedano-López, P. (2002). Language Socialization: Reproduction and Continuity, Transformation and Change. Annual Review of Anthropology, 31(1), 339-361.

Garrido, M. R. (2018). Circulation and Localization of a Transnational Founding Story in a Social Movement. International Journal of the Sociology of Language, 250, 113-135.

Humphreys, K. (2000). Community Narratives and Personal Stories in Alcoholics Anonymous. Journal of Community Psychology, 28(5), 495-506.

Le Boursicaud, H. (1979). Compagnons d'Emmaüs. Paris: Le Cherche Midi.

Linde, C. (2009). Working the Past: Narrative and Institutional Memory. Working the Past: Narrative and Institutional Memory. Oxford: Oxford University Press.

McFague TeSelle, S. (1974). Parable, Metaphor, and Theology. Journal of the American Academy of Religion, 42(4), 630-645.

Melucci, A. (1995). The Process of Collective Identity. In H. Johnston \& B. Klandermans (Eds.), Social Movements and Culture (pp. 41-63). London: University College London.

Patiño-Santos, A. (2018). Introduction. International Journal of the Sociology of Language, 250, 1-10.

Polletta, F., \& Jasper, J. M. (2001). Collective Identity and Social Movements. Annual Review of Sociology, 27(1), 283-305.

Schiffrin, D. (2009). Crossing Boundaries: The Nexus of Time, Space, Person, and Place in Narrative. Language in Society, 38, 421-445.

Silverstein, M. (2005). Axes of Evals: Token versus Type Interdiscursivity. Journal of Linguistic Anthropology, 15(1), 6-22.

Simon, B. (1954). Les chiffoniers d'Emmaüs. Paris: Editions du Seuil.

Stasch, R. (2011). Textual Iconicity and the Primitivist Cosmos: Chronotopes of Desire in Travel Writing about Korowai of West Papua. Journal of Linguistic Anthropology, 21(1), 1-21.

Woolard, K. A. (2013). Is the Personal Political? Chronotopes and Changing Stances toward Catalan Language and Identity. International Journal of Bilingual Education and Bilingualism, 16(2), 210-224.

Wortham, S., Mortimer, K., Lee, K., Allard, E., \& White, K. D. (2011). Interviews as Interactional Data. Language in Society, 40, 39-50.

Agha, A. (2007). Recombinant Selves in Mass Mediated Spacetime. Language and Communication, 27, 320-335. 
Agrikoliansky, É., Filleule, O., \& Mayer, N. (2005). L'Altermondialisme en France: La Longue Histoire d'une Nouvelle Cause. Paris: Flammarion.

Alcock, P. (2012). Big Society or Civil Society? A New Policy Environment for the Third Sector (No. 82). Retrieved from: https://www.birmingham. ac.uk/Documents/college-social-sciences/social-policy/tsrc/working-papers/ working-paper-82.pdf [Date accessed: 8 May 2020]

Allan, K. (2016). Going beyond Language: Soft Skill-ing Cultural Difference and Immigrant Integration in Toronto, Canada. Multilingua, 35(6), 617-647.

Allan, K. (2019). Volunteering as Hope Labour: The Potential Value of Unpaid Work Experience for the Un- and Under-Employed. Culture, Theory and Critique, 60(1), 66-83.

Bakhtin, M. M. (1981). The Dialogic Imagination. (M. Holquist, Ed.). Austin: University of Texas Press.

Beyer, P. (1994). Religion and Globalization. London: SAGE.

Bowgett, K. (2006). Homeless People and Volunteering. Voluntary Action, 7(3), 11-29.

Brodiez-Dolino, A. (2013). Emmaus and the Abbé Pierre: An Alternative Model of Enterprise, Charity and Society. Paris: Presse de Sciences Po.

Castells, M. (2012). Networks of Outrage and Hope: Social Movements in the Internet Age. Cambridge: Polity.

Corbett, S., \& Walker, A. (2012). The Big Society: Back to the Future. The Political Quarterly, 83(3), 487-492.

Couture, D. (2010). Théologies Chrétiennes et Mouvance Altermondialiste: Quelques Points d'Intersections. Théologiques, 18(1), 37-63.

Department for Communities and Local Government. (2013). Rough Sleeping Statistics England - Autumn 2012 Experimental Statistics. Retrieved from: https://assets.publishing.service.gov.uk/government/uploads/system/uploads/ attachment_data/file/284278/Rough_Sleeping_Statistics_England_-_ Autumn_2012_-_REVISED.pdf [Date accessed: 5 June 2020]

Fernández Buey, F. (2007). Sobre el Movimiento de Movimientos. In R. Prieto Lacaci (Ed.), Jóvenes, Globalización y Movimientos Altermundistas (pp. 21-38). Madrid: Instituto de la Juventud.

Fougier, E. (2012). De l'Altermondialisme aux «Indignés » : Un Nouveau Souffle pour la Contestation du Capitalisme ? Revue Internationale et Stratégique, $86(2), 26$.

Gal, S. (2003). Movements of Feminism: The Circulation of Discourses about Women. In B. Hobson (Ed.), Recognition Struggles and Social Movements: Contested Identities, Agency and Power (pp. 93-120). Cambridge: Cambridge University Press.

Gal, S. (2007). Circulation in the "New" Economy: Clasps and Copies. Washington, DC: Paper presented at the 106th Meeting of the American Anthropological Association.

Ganz, M. (2010). Leading Change: Leadership, Organization and Social Movements. In N. Nohria and R. Khurana (Eds.), Handbook of Leadership Theory and Practice: A Harvard Business School Centennial Colloquium (pp. 527-568). Boston (MA): Harvard Business Press.

Garrido, M. R. (2010). "If You Slept in Catalunya You Know That Here It's a Paradise": Multilingual Practices and Ideologies in a Residential Project for Migrants. Unpublished MA Thesis: Universitat Autònoma de Barcelona. 
Garrido, M. R. (2016). “The Homeless Charity That Works”: A Critical Sociolinguistic Analysis of Charity Discourses and English-only Ideologies in Emmaus London. Bulletin Suisse de Linguistique Apliquée, 104, 9-26.

Gómez Gil, C. (2005). Las ONG en España: De la Apariencia a la Realidad. Madrid: Catarata.

Hardt, M. (1999). Affective Labour. Boundary, 26(2), 89-100.

Hessel, S. (2010). Indignez-vous! Montpellier: Indigène Éditions.

Hochschild, A. R. (1983). The Managed Heart: Commercialization of Human Feeling. Berkeley and Los Angeles: University of California Press.

Jones, A., \& Pleace, N. (2010). A Review of Single Homelessness in the UK 2000 - 2010. London. Retrieved from: https://www.crisis.org.uk/ media/237174/a_review_of_single_homelessness_in_the_uk_2000-2010_es .pdf [Date accessed: 8 May 2020]

Mangot Sala, L. (2013). Cronología: Burbuja, Crisis y PAH. Anuari Del Conflicte Social, 272-283. Retrieved from: http://revistes.ub.edu/index.php/ACS/ article/view/10338 [Date accessed: 5 June 2020]

Martín-Rojo, L. (2016a). Occupy: The Spatial Dynamics of Discourse in Global Protest Movements. In L. Martín-Rojo (Ed.), Occupy: The Spatial Dynamics of Discourse in Global Protest Movements (pp. 1-22). Amsterdam and Philadelphia, PA: John Benjamins.

Martín-Rojo, L. (2016b). Taking over the Square: The Role of Linguistic Practices in Contesting Urban Spaces. In L. Martín-Rojo (Ed.), Occupy: The Spatial Dynamics of Discourse in Global Protest Movements (pp. 47-76). Amsterdam and Philadelphia, PA: John Benjamins.

Muehlebach, A. (2009). Complexio Oppositorum: Notes on the Left in Neoliberal Italy. Public Culture, 21(3), 495-515.

Muehlebach, A. (2012). The Moral Neoliberal. The Moral Neoliberal: Welfare and Citizenship in Italy. Chicago, IL and London: The University of Chicago Press.

Parenteau, I. (2011). Tableau d'ensemble de l'altermondialisme Clés de lecture de l'altermondialisme de François Polet, Bruxelles, Couleur livres, 2008, 84 p. I Dictionnaire analytique de l'altermondialisme d'Eddy Fougier, Paris, Ellipses, 2006, 287 p. L’Altermondialisme de Francis Dupuis-Déri, Montréal, Boréal, coll. "Boréal Express ", 2009, 127 p. / Généalogie des mouvements altermondialistes en Europe. Une perspective comparée, sous la dir. d'Isabelle Sommier, Olivier Fillieule et Éric Agrikoliansky, Paris, Karthala, coll. "Science politique comparative », 2008, 293 p. Politique et Sociétés, 30 (2), 203-223.

Pech, T., \& Padis, M. O. (2004). Multinationales du Coeur: Les ONG, la Politique et le Marché. Paris: Seuil.

Pennycook, A. (2010). Language as a Local Practice. London and New York: Routledge.

Pianta, M., \& Zola, D. (2008). La Montée en Puissance des Mouvements Globaux 1970-2005. In I. Sommier, O. Filleule, \& É. Agrikoliansky (Eds.), Généalogie des Mouvements Altermondialistes en Europe: Une Perspective Comparée (pp. 41-66). Paris: Éditions Karthala.

Rozakou, K. (2016). Crafting the Volunteer: Voluntary Associations and the Reformation of Sociality. Journal of Modern Greek Studies, 34(1), 79-102.

Urciuoli, B. (2008). Skills and Selves in the New Workplace. American Ethnologist, 35(2), 211-228. 
Ambroisine, J. (2014). Les Communautés Emmaüs en Europe. Revue Internationale de l'Économie Sociale, 332, 74-92.

Brodiez-Dolino, A. (2013). Emmaus and the Abbé Pierre: An Alternative Model of Enterprise, Charity and Society. Paris: Presse de Sciences Po.

Castells, M. (1996). The Rise of the Network Society, The Information Age: Economy, Society and Culture Vol. I. Cambridge, MA, and Oxford: Blackwell.

Cornips, L., \& de Rooij, V. (2018). Introduction: Belonging Through Linguistic Place-Making. In L. Cornips \& V. de Rooij (Eds.), The Sociolinguistics of Place and Belonging: Perspectives from the Margins (pp. 1-16). Amsterdam and Philadelphia, PA: John Benjamins.

Deleuze, G., \& Guattari, F. (1987). A Thousand Plateaus: Capitalism and Schizophrenia. Minneapolis and London: University of Minnesota Press.

Freire, P. (1970). Pedagogy of the Oppressed. New York: Continuum.

Garrido, M. R. (2018). Voluntary Work, Transnational Mobility and Language Learning in a Social Movement. Language and Intercultural Communication, 18(4), 451-463.

Gille, Z., \& Ó Riain, S. (2002). Global Ethnography. Annual Review of Sociology, 28, 271-295.

Irvine, J. T. (1989). When Talk Isn't Cheap : Language and Political Economy. American Ethnologist, 16(2), 248-267.

Irvine, J. T. (2012). Language Ideology. In Anthropology-Oxford Bibliographies. Jaffe, A. (2009). Stance in a Corsican School: Institutional and Ideological Orders and the Production of Bilingual Subjects. In A. Jaffe (Ed.), Stance: Sociolinguistic Perspectives (pp. 119-145). Oxford: Oxford University Press.

Kahn, E., \& Heller, M. (2006). Idéologies et Pratiques du Multilinguisme au Québec : Luttes et Mutations dans un Site de la Nouvelle Économie. Langage et Société, 118(4), 43-63.

Muehlmann, S. (2012). Rhizomes and Other Uncountables: The Malaise of Enumeration in Mexico's Colorado River Delta. American Ethnologist, 39(2), 339-353.

Park, J. S. Y., \& Wee, L. (2012). Markets of English: Linguistic Capital and Language Policy in a Globalizing World. New York: Routledge.

Pech, T., \& Padis, M. O. (2004). Multinationales du Coeur: Les ONG, la Politique et le Marché. Paris: Seuil.

Piller, I., \& Cho, J. (2013). Neoliberalism as Language Policy. Language in Society, 42, 23-44.

Pries, L. (2001). The Approach of Transnational Social Spaces: Responding to New Configurations of the Social and the Spatial. In L. Pries (Ed.), New Transnational Social Spaces: International Migration and Transnational Companies in the Early Twenty-First Century (pp. 3-29). London and New York: Routledge.

Simon, B. (1954). Les Chiffoniers d'Emmaüs. Paris: Editions du Seuil.

Urla, J. (1993). Cultural Politics in an Age of Statistics: Numbers, Nations, and the Making of Basque Identity. American Ethnologist, 20(4), 818-843.

Wenger, E. (1998). Communities of Practice: Learning, Meaning, and Identity. Cambridge: Cambridge University Press.

Ambroisine, J. (2014). Les Communautés Emmaüs en Europe. Revue Internationale de l'Économie Sociale, 332, 74-92. 
Brodiez-Dolino, A. (2013). Emmaus and the Abbé Pierre: An Alternative Model of Enterprise, Charity and Society. Paris: Presse de Sciences Po.

Castells, M. (1996). The Rise of the Network Society, The Information Age: Economy, Society and Culture Vol. I. Cambridge, MA, and Oxford: Blackwell.

Cornips, L., \& de Rooij, V. (2018). Introduction: Belonging Through Linguistic Place-Making. In L. Cornips \& V. de Rooij (Eds.), The Sociolinguistics of Place and Belonging: Perspectives from the Margins (pp. 1-16). Amsterdam and Philadelphia, PA: John Benjamins.

Deleuze, G., \& Guattari, F. (1987). A Thousand Plateaus: Capitalism and Schizophrenia. Minneapolis and London: University of Minnesota Press.

Freire, P. (1970). Pedagogy of the Oppressed. New York: Continuum.

Garrido, M. R. (2018). Voluntary Work, Transnational Mobility and Language Learning in a Social Movement. Language and Intercultural Communication, 18(4), 451-463.

Gille, Z., \& Ó Riain, S. (2002). Global Ethnography. Annual Review of Sociology, 28, 271-295.

Irvine, J. T. (1989). When Talk Isn't Cheap : Language and Political Economy. American Ethnologist, 16(2), 248-267.

Irvine, J. T. (2012). Language Ideology. In Anthropology-Oxford Bibliographies. Jaffe, A. (2009). Stance in a Corsican School: Institutional and Ideological Orders and the Production of Bilingual Subjects. In A. Jaffe (Ed.), Stance: Sociolinguistic Perspectives (pp. 119-145). Oxford: Oxford University Press.

Kahn, E., \& Heller, M. (2006). Idéologies et Pratiques du Multilinguisme au Québec : Luttes et Mutations dans un Site de la Nouvelle Économie. Langage et Société, 118(4), 43-63.

Muehlmann, S. (2012). Rhizomes and Other Uncountables: The Malaise of Enumeration in Mexico's Colorado River Delta. American Ethnologist, 39(2), 339-353.

Park, J. S. Y., \& Wee, L. (2012). Markets of English: Linguistic Capital and Language Policy in a Globalizing World. New York: Routledge.

Pech, T., \& Padis, M. O. (2004). Multinationales du Coeur: Les ONG, la Politique et le Marché. Paris: Seuil.

Piller, I., \& Cho, J. (2013). Neoliberalism as Language Policy. Language in Society, 42, 23-44.

Pries, L. (2001). The Approach of Transnational Social Spaces: Responding to New Configurations of the Social and the Spatial. In L. Pries (Ed.), New Transnational Social Spaces: International Migration and Transnational Companies in the Early Twenty-First Century (pp. 3-29). London and New York: Routledge.

Simon, B. (1954). Les Chiffoniers d'Emmaüs. Paris: Editions du Seuil.

Urla, J. (1993). Cultural Politics in an Age of Statistics: Numbers, Nations, and the Making of Basque Identity. American Ethnologist, 20(4), 818-843.

Wenger, E. (1998). Communities of Practice: Learning, Meaning, and Identity. Cambridge: Cambridge University Press.

Wimmer, A., \& Glick Schiller, N. (2002). Methodological Nationalism and Beyond: Nation-state Building, Migration and the Social Sciences. Global Networks, 2(4), 301-334. 
Woolard, K. A. (forthcoming). Language Ideologies. In J. Stanlaw (Ed.), International Encyclopedia of Linguistic Anthropology. Wiley-Blackwell.

Woolard, K. A. (1998). Introduction: Language Ideology as a Field of Inquiry. In B. B. Schieffelin, K. A. Woolard, \& P. V. Korskrity (Eds.), Language Ideologies: Practice and Theory (pp. 3-47). New York, Oxford: Oxford University Press.

Woolard, K. A. (2016). Singular and Plural: Ideologies of Linguistic Authority in 21st Century Catalonia. Oxford: Oxford University Press.

Woolard, K. A. (2018). Playing Against Peripheralization: A Commentary. In L. Cornips \& V. de Rooij (Eds.), The Sociolinguistics of Place and Belonging: Perspectives from the Margins (pp. 115-125). Amsterdam and Philadelphia, PA: John Benjamins.

Anderson, B. (1983). Imagined Communities: Reflections on the Origin and Spread of Nationalism (3rd ed.). London: Verso.

Billig, M. (1995). Banal Nationalism. London: Sage.

Blommaert, J., \& Backus, A. (2011). Repertoires Revisited: "Knowing Language" in Superdiversity. Working Papers in Urban Language and Literacies 67. Retrieved from: http://www.kcl.ac.uk/sspp/departments/education/ research/ldc/publications/workingpapers/67.pdf [8th September 2014]

Bourdieu, P. (1982). Ce que Parler Veut Dire. Paris: Fayard.

Bourdieu, P. (1991). Language and Symbolic Power. Cambridge: Polity Press.

Bretherton, J., \& Pleace, N. (2012). New Growth for Emmaus. Research Report. Centre for Housing Policy, The University of York. Retrieved from: http:// eprints.whiterose.ac.uk/74312/1/Emmauspubformat.pdf [1st April 2018]

Codó, E., \& Garrido, M. R. (2010). Ideologies and Practices of Multilingualism in Bureaucratic and Legal Advice Encounters. In R. Márquez-Reiter \& L. Martín-Rojo (Eds.), Service Provision in a Globalised World. Special Issue of Sociolinguistic Studies, 4(2), 297-332.

Codó, E., \& Garrido, M. R. (2014). Shifting Discourses of Migrant Incorporation at a Time of Crisis: Understanding the Articulation of Language and Labour in the Catalan Non-governmental Sector. In E. Codó \& M. PérezMilans (Eds.), Multilingual Discursive Practices and Processes of Social Change in Globalizing Institutional Spaces. Special Issue of International Journal of Multilingualism, 11(4), 389-408.

Condor, S. (2000). Pride and Prejudice: Identity Management in English People's Talk about 'This Country'. Discourse and Society, 11(2), 175-205.

Condor, S., \& Abell, J. (2006). Vernacular Constructions of 'National Identity' in Post-Devolution Scotland and England. In J. Wilson \& K. Stapleton (Eds.), Devolution and Identity (pp. 51-76). London and New York: Routledge.

Corona, V., Nussbaum, L., \& Unamuno, V. (2013). The Emergence of New Linguistic Repertoires among Barcelona's Youth of Latin American Origin. International Journal of Bilingual Education and Bilingualism, 16(2), 182-194.

Flubacher, M. C., Duchêne, A., \& Coray, R. (2018). Language Investment and Employability: The Uneven Distribution of Resources in the Public Employment Service. New York: Palgrave Macmillan.

Gal, S., \& Woolard, K. A. (2001). Constructing Languages and Publics: Authority and Representation. In S. Gal \& K. A. Woolard (Eds.), Languages and Publics: The Making of Authority (pp. 1-12). Manchester: St. Jerome Publishing. Garrido, M. R. (2010). "'If You Slept in Catalunya You Know That Here It's a 
Paradise': Multilingual Practices and Ideologies in a Residential Project for Migrants". Unpublished MA Thesis: Universitat Autònoma de Barcelona.

Garrido, M. R. (2018). Voluntary Work, Transnational Mobility and Language Learning in a Social Movement. In M. Moyer (Ed.), Language, Mobility and Work. Special Issue of Language and Intercultural Communication, 18(4), 451-463.

Garrido, M. R. (2019). Language Socialisation and Muda: The Case of Two Transnational Migrants in Emmaus Barcelona. In R. Márquez-Reiter \& L. Martín-Rojo (Eds.), Linguistics of Participation and Exclusion: New Speakers' Struggles for Mobility in Europe. Special Issue of International Journal of the Sociology of Language, 257, 137-163.

Gatt, C. (2018). An Ethnography of Global Environmentalism: Becoming Friends of the Earth. New York and Oxon: Routledge.

Generalitat de Catalunya. (2010). Llei d'Acollida de les Persones Immigrades $i$ Retornades a Catalunya [Reception law for immigrants and returnees to Catalonia]. Barcelona: Departament d'Acció Social i Ciutadania, Secretaria per a la Immigració.

Harvey, D. (2005). A Brief History of Neoliberalism. Oxford: Oxford University Press.

Hogan-Brun, G., Mar-Molinero, C., \& Stevenson, P. (Eds.). (2009). Discourses on Language and Integration: Critical Perspectives on Language Testing Regimes in Europe. Amsterdam: John Benjamins.

Inda, J. X. (2006). Targeting Immigrants: Government, Technology, and Ethics. Oxford: Wiley-Blackwell.

Irvine, J. T., \& Gal, S. (2000). Language Ideology and Linguistic Differentiation. In P. Kroskrity (Ed.), Regimes of Language (pp. 35-83). Santa Fe, NM: School of American Research Press.

Jaffe, A. (2009). Stance in a Corsican School: Institutional and Ideological Orders and the Production of Bilingual Subjects. In A. Jaffe (Ed.), Stance: Sociolinguistic Perspectives (pp. 119-145). Oxford: Oxford University Press.

Jørgensen, J. N. (2008). Polylingual Languaging Around and among Children and Adolescents. International Journal of Multilingualism, 5, 161-176.

Kachuk, P. (1994). A Resistance to British Cultural Hegemony: Irish-language Activism in West Belfast. Anthropologica, 36(2), 135-154.

Kahn, E., \& Heller, M. (2006). Idéologies et Pratiques du Multilinguisme au Québec: Luttes et Mutations dans un Site de la Nouvelle Économie. Langage et Société, 118, 43-63.

Otsuji, E., \& Pennycook, A. (2010). Metrolingualism: Fixity, Fluidity and Language in Flux. International Journal of Multilingualism, 7(3), 240-254.

Park, J. S. (2013). Metadiscursive Regimes of Diversity in a Multinational Corporation. Language in Society, 42(5), 557-577.

Pujolar, J. (2007a). Bilingualism and the Nation-state in the Post-national Era. In M. Heller (Ed.), Bilingualism: A Social Approach (pp. 71-95). Houndsmills, Basingstoke, Hampshire and New York : Palgrave Macmillan.

Pujolar, J. (2007b). African Women in Catalan Language Courses: Struggles over Class, Gender and Ethnicity in Advanced Liberalism. In B. McElhinny (Ed.), Words, Worlds and Material Girls: Language, Gender, Globalisation (pp. 305-348). Berlin: Mouton de Gruyter.

Pujolar, J., \& Gonzàlez, I. (2013). Linguistic "Mudes" and the De-ethnicization of Language Choice in Catalonia. International Journal of Bilingual Educa- 
tion and Bilingualism, 16(2), 138-152.

Pujolar, J., \& Puigdevall, M. (2015). Linguistic Mudes: How to Become a New Speaker in Catalonia. International Journal of the Sociology of Language, 231, 167-187.

Rampton, B. (1995). Crossing: Language and Ethnicity among Adolescents. London: Longman.

Roberts, C. (2013). The Gatekeeping of Babel: Job Interviews and the Linguistic Penalty. In A. Duchêne, M. G. Moyer, \& C. Roberts (Eds.), Language, Migration and Social Inequalities: A Critical Sociolinguistic Perspective on Institutions and Work (pp. 81-94). Bristol: Multilingual Matters.

Skey, M. (2009). The National in Everyday Life: A Critical Engagement with Michael Billig's Thesis of Banal Nationalism. The Sociological Review, 57(2), 331-346.

Strömmer, M. (2016). Affordances and Constraints: Second Language Learning in Cleaning Work. Multilingua: Journal of Cross-Cultural and Interlanguage Communication, 35(6), 697-721.

Urla, J. (2012). Reclaiming Basque: Language, Nation, and Cultural Activism. Reno: University of Nevada Press.

Woolard, K. A. (1989). Double Talk: Bilingualism and the Politics of Ethnicity in Catalonia. Stanford, CA: Stanford University Press.

Woolard, K. A. (1998). Simultaneity and Bivalency as Strategies in Bilingualism. Journal of Linguistic Anthropology, 8(1), 3-29.

Woolard, K. A. (2008). Language and Identity Choice in Catalonia: The Interplay of Contrasting Ideologies of Linguistic Authority. In K. Süselbeck, U. Mühlschlegel, \& P. Masson (Eds.), Lengua, Nación e Identidad: La Regulación del Plurilingüismo en España y América Latina (pp. 303-323). Frankfurt am Main: Vervuert and Madrid: Iberoamericana.

Woolard, K. A. (2016). Singular and Plural: Ideologies of Linguistic Authority in 21st Century Catalonia. Oxford and New York: Oxford University Press.

Woolard, K. A., \& Frekko, S. E. (2013). Catalan in the Twenty-first Century: Romantic Publics and Cosmopolitan Communities. International Journal of Bilingual Education and Bilingualism, 16(2), 129-137.

Appadurai. A. (2000). Grassroots Globalization and the Research Imagination. Public Culture, 12(1), 1-19.

Blommaert, J. (2010). The Sociolinguistics of Globalisation. Cambridge: Cambridge University Press.

Brodiez-Dolino, A. (2008). Emmaüs et l'Abbé Pierre. Paris: Les Presses de Sciences Po.

Castells, M. (2012). Networks of Outrage and Hope: Social Movements in the Internet Age. Cambridge: Polity.

Codó, E. (2008). Immigration and Bureaucratic Control: Language Practices in Public Administration. Berlin: Mouton de Gruyter.

Foucault, M. (1991). Discipline and Punish: The Birth of a Prison. London: Penguin.

Gal, S. (2007, December). Circulation in the "New" Economy: Clasps and Copies. Paper presented at the 106th Meeting of the American Anthropological Association, Washington, DC.

Galeano, E. (1993). Las Palabras Andantes. Madrid: Siglo XXI. 
Ganz, M. (2010). Leading Change: Leadership, Organization, and Social Movements. In N. Nohria \& R. Khurana (Eds.), Handbook of Leadership, Theory and Practice: A Harvard Business School Centennial Colloquium (pp. 527-568). Boston, MA: Harvard Business Press.

Garrido, M. R. (2018). Voluntary Work, Transnational Mobility and Language Learning in a Social Movement. Language and Intercultural Communication, 18(4), 451-463.

Hessel, S. (2010). Indignez-vous!. Montpellier: Indigène Éditions.

Irvine, J. T., \& Gal, S. (2000). Language Ideology and Linguistic Differentiation. In P. Kroskrity (Ed.), Regimes of Language (pp. 35-83). Santa Fe, NM: School of American Research Press.

Lefèvre, D. (2001). Les Combats d'Emmaüs. Paris: Le Cherche Midi.

Martín-Rojo, L. (Ed.). (2016). Occupy: The Spatial Dynamics of Discourse in Global Protest Movements. Amsterdam and Philadelphia, PA: John Benjamins.

Pennycook, A. (2007). Global Englishes and Transcultural Flows. Abingdon: Routledge.

Portes, A. (2001). Introduction: The Debates and Significance of Immigrant Transnationalism. Global Networks, 1(3), 181-193.

Schneider, B. (2014). Salsa, Language and Transnationalism. Bristol: Multilingual Matters.

Simon, B. (1954). Les Chiffoniers d'Emmaüs. Paris: Editions du Seuil. 